\title{
Hypothetic Reconstruction of The Development of The Defensive Structures of The Middle Town of Rohatyn in $15^{\text {th }}-17^{\text {th }}$ Centuries
}

\author{
Mykola Bevz \\ e-mail: bevzmist@polynet.lviv.ua
}

Department of Architecture and Conservation, L'viv Polytechnic National University, Department of Built Conservation, Lublin University of Technology

\begin{abstract}
On the Rohatyn example we want to demonstrate:
a) how the battles, assault and destruction of the town influenced the character of its urban and architectural development (as shown by the example of the Battle of 1509 and the events of World War I);

b) how important the fortification element was in the past in towns of Halychyna region;

c) what methodology can be used to reconstruct the stages of development of urban fortifications, given that today they are almost completely lost;

d) the importance of a thorough analysis of the current state of the territory and the town's relief, the study of historical documents, analysis of cartographic materials and iconographic sources for the theoretical reconstruction of stages of development of fortifications.
\end{abstract}

The town of Rohatyn belongs to the oldest urban locations that existed according to the German (Magdeburg) law in the territory of Western Ukraine. The great chronological depth of the town's urban structure has been often mentioned by researchers. However, academic literature does not yet fully cover the changes made to the planning of the town's structure during the $15^{\text {th }}-17^{\text {th }}$ centuries. Similarly, the stages of development of the town's defensive lines were not identified, although historical documents contain many references to the existence of fortifications around the middle town and the castle. Existing documentation only describes the urban changes in general terms, with researchers not yet having organized them into specific planning schemes. In our present work, we set our goal as the reconstruction of the different stages of development of fortifications of the original walled medieval town of Rohatyn. We use the following methodology: analysis of the town's planning structure based on both historical and contemporary maps; studies of the remains of fortifications in the current landscape; comparison of field studies with data from cartographic analysis to references to the defensive objects found in historical documents; studies of analogical landmarks; and graphical reconstruction of stages of development of fortifications. According to our research, the fortification history of the town can be divided into four main stages.

$1^{\text {st }}$ stage - between 1415 AD (date of the town's founding) and 1509 AD (complete demolition of the town as a result of the attack of the Wallachian-Turkish army).

$2^{\text {nd }}$ stage - from 1509 AD to approximately $1539 A D$. The town within the walls of the surrounding fortification is restored on the basis of new royal privileges given in 1523, 1535 and 1539. The town is able to develop, with new fortifications being built around the residential and commercial districts of the town and the castle.

$3^{\text {rd }}$ stage - from 1539 AD to the end of the $16^{\text {th }}$ century. A new district called the "New Town" was created to the west of the old walled town, with a new belt of earth bastion fortifications. At the end of this period, the bank form of the defenses was modernized into the bastion forms.

$4^{\text {th }}$ stage - the $17^{\text {th }}$ century. The town's fortifications continue to be maintained in good condition and upgraded. The territorial expansion of the town to the south led to the emergence of new residential neighborhoods and the creation of additional bastion fortifications to the east and south of the borders of the New Town.

Our research has shown that Rohatyn is a unique town in aspects of the development of fortification systems in the $15^{\text {th }}$ and $17^{\text {th }}$ centuries in Ukraine.

Keywords: town of Rohatyn, fortification, earthen ramparts, basteja (bastia), bastion, $15-17^{\text {th }}$ centuries. 


\section{Introduction. Research relevance}

Rohatyn is a town in western Ukraine that was twice destroyed almost completely. The first time it happened in 1509, during the incursion of the Wallachian-Turkish army. The second time the town was destroyed in the First World War. After the first destruction, the town was revived, paying much attention to the construction of fortifications.

In our present work, we try to reconstruct the stages of development of the town's fortifications by means of the identification of the planning structure occurring at different times based on our experience in this field (M.Bevz, 1996, 1997, 1998, 2000, 2002, 2004). We consider this problem to be relevant because in the works of predecessors [J.S. Zubrzycki, 1911; F.D. Wąsowicz, 1879; Matsyuk O., 1997; Melnyk V., 1991; Pankiv B., 1995; Yasinskyi M., 2004] due attention was not paid to the presence in the town's planning structure of remnants of fortifications lines - including bastion fortifications - that belong to different stages (fig. 1).

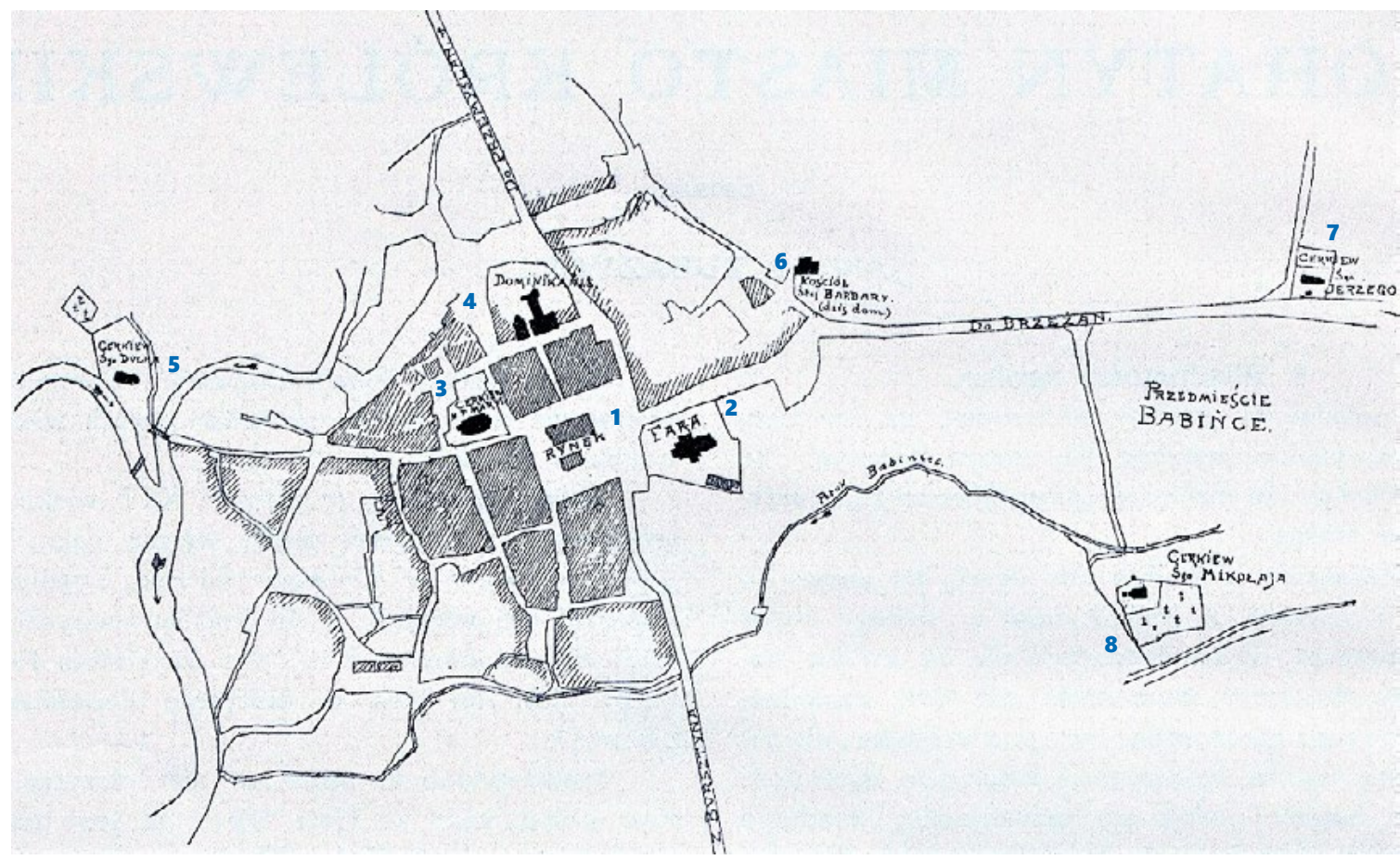

Fig. 1. The plan of the town of Rohatyn at the beginning of the twentieth century by Jan Sas Zubrzycki [J.S. Zubrzycki, 1914, s. 5]. Marked: 1 - Rynok Square, 2 - St. Nicholas Church, 3 - Tserkva of the Nativity of the Virgin Mary Mary, 4 - Dominican Church and Monastery, 5 - wooden Tserkva of the Holy Spirit, 6-St. Barbara Church, 7 - St. Yurii Tserkva, 8 - wooden Tserkva of St. Mykola.

In 1992-1993, a plan based on historical and architectural studies of Rohatyn was developed. The authors determined the zone of defensive rampart location around the medieval fortified town and made the hypothesis that medieval Rohatyn had two gates - Lviv and Halych Gates - which were located in the western and eastern curtain walls of the fortifications [R. Mohytych, 1995; 1996]. Subsequently, in 2007, a new historical and architectural plan of Rohatyn was developed. Unfortunately, this research and project documentation also did not detail the identification of defensive lines and planning changes in the town plan during the $15^{\text {th }}-17^{\text {th }}$ centuries (Fig. 2). 


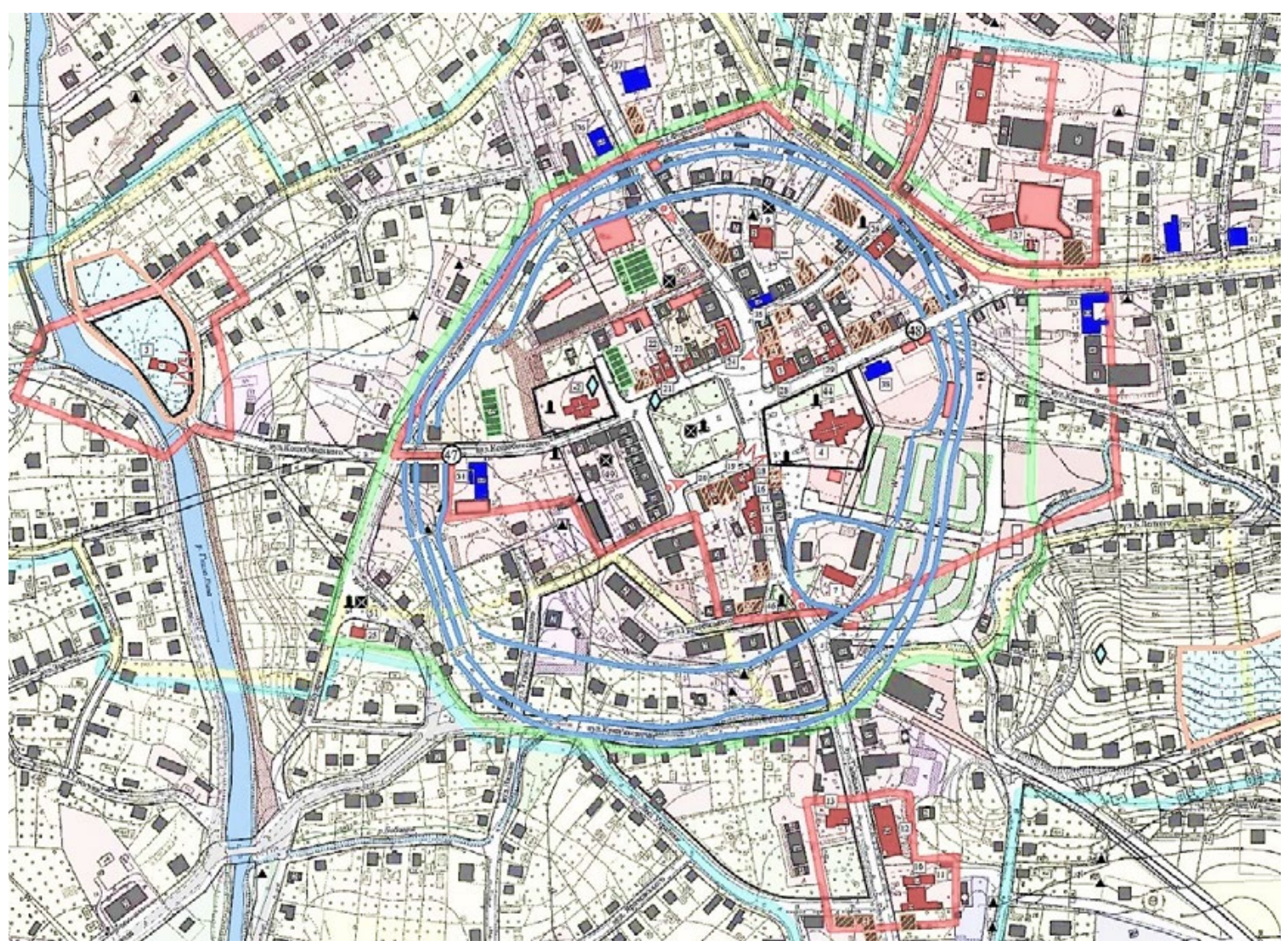

Fig. 2. Plan based on historical and architectural studies of the town of Rohatyn (fragment). UDNPI "Dipromisto", 2007, authors Shumin I., Shubelyak N., Senchak Z. Three concentric circles indicate the probable lines of fortifications around the city center, as well as the location of the castle.

In the writings of historians who described the architectural and urban development of Rohatyn, the stages of urban changes were presented only in general context without reconstructing them into specific planning schemes [J.S. Zubrzycki, 1914; F.D. Wąsowicz, 1869; A. Czołowski, 1930; Melnyk V., 1991]. For example, the architect J.S. Zubrzycki mentioned the existence of fortifications around the middle town, fixed individual residues of the ramparts on the site, but did not reinforce this information by planning schemes (Fig. 1) [J.S. Zubrzycki, 1914]. Reconstructions of the planning structure and developmental stages of the middle town fortifications were performed by several more authors. In 1996, a version of the town's planning in the late $16^{\text {th }}$ - early $17^{\text {th }}$ century was published by R. Mohytych (Fig. 3). According to the hypothesis of the author, the middle town was surrounded by a defensive rampart in a circle with two gates - in the western and eastern parts - and with a wicket in the southwestern part. The defensive towers on the rampart were not marked by the author. According to his layout, the castle was located in the middle of the town, but it had its own rampart line closed in a small circle with a gate from the church side. There was only one palace building in the castle. The author mistakenly indicated the location of the New Town district to the north of the middle town. In fact, there were ponds and mills, and the new district was located to the west and to the south of the Lviv gate.

Very "bold" is the reconstruction of the middle town planning by M. Yasinskyi (Fig. 4), made under supervision of associate professor O. Rybchynskyi [M. Yasinskyi, 2013]. However, the form of masonry towers and walls for the period of $16^{\text {th }}-17^{\text {th }}$ centuries which were proposed by the authors is not consistent with historical documents which mention wooden fortifications of the town during this period.

Our analysis of the modern plan of the town's central part showed the presence of planning elements (quarters and street network) of triangular shape (Fig. 10, 7). The middle town is distinguished by a well-planned regular rectangular grid of streets. We believe that these irregular quarter and street planning forms should be linked with a sketch of previous fortifications. 


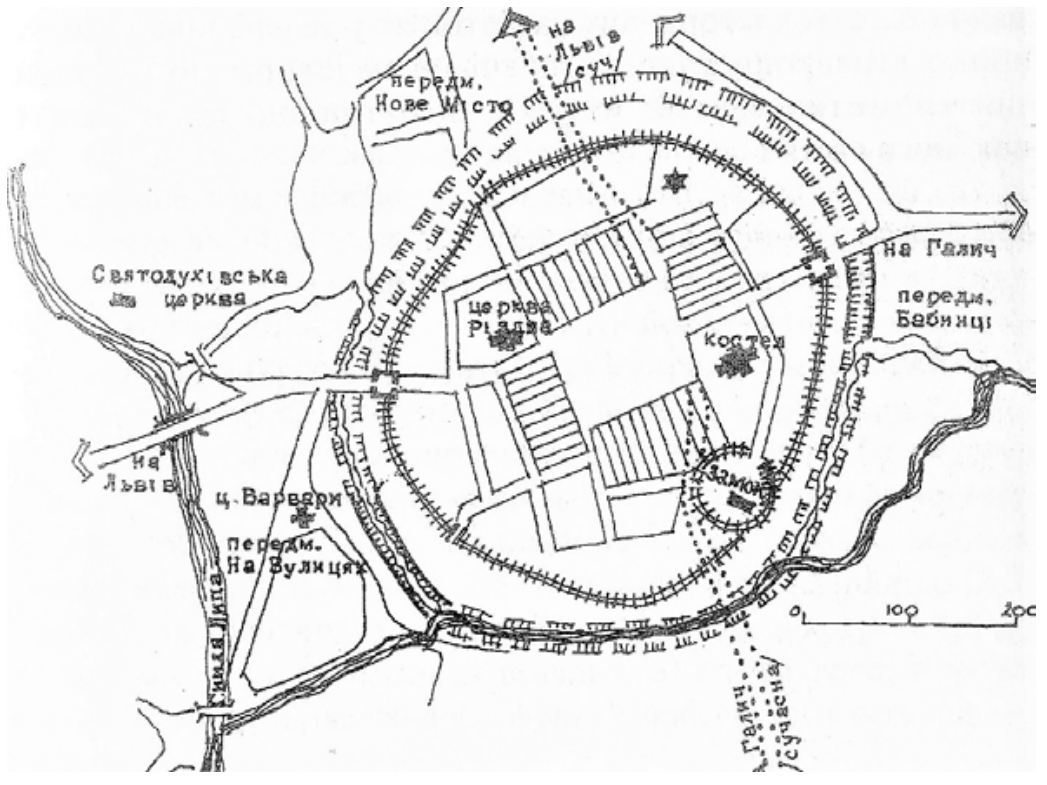

Fig. 3. Hypothetical reconstruction of planning structure of Rohatyn (XVI - early XVII century) by R.Mohytych [Mohytych R., 1996].

\section{Presentation of the main material. An outline of the historical stages of the development of the middle town of Rohatyn}

Many historians mentioned the great chronological depth of the town structure, attributing Rohatyn to the oldest cities in Halychyna [J.S. Zubrzycki, 1914]. The town received a locational privilege from Vladislaus II of Opole in 1415 [Tsariova N., 1995]. It was a privilege for a private location. The founding of the town is associated with the noble Volchko Presluzhych. At that time, such founding was realized through the expansion of a fortified middle town with ramparts or masonry walls with a square or rectangular market square in the middle. In the case of Rohatyn, this square has survived to this day. Instead, the lines of fortifications are completely lost and their location is rather problematic, since archaeological research of their remains has not yet been carried out. The remnants of ramparts, in particular, are recorded in the historical and architectural key plan of the town, but without clear stylistic or temporal identification of these remnants (Fig. 2).
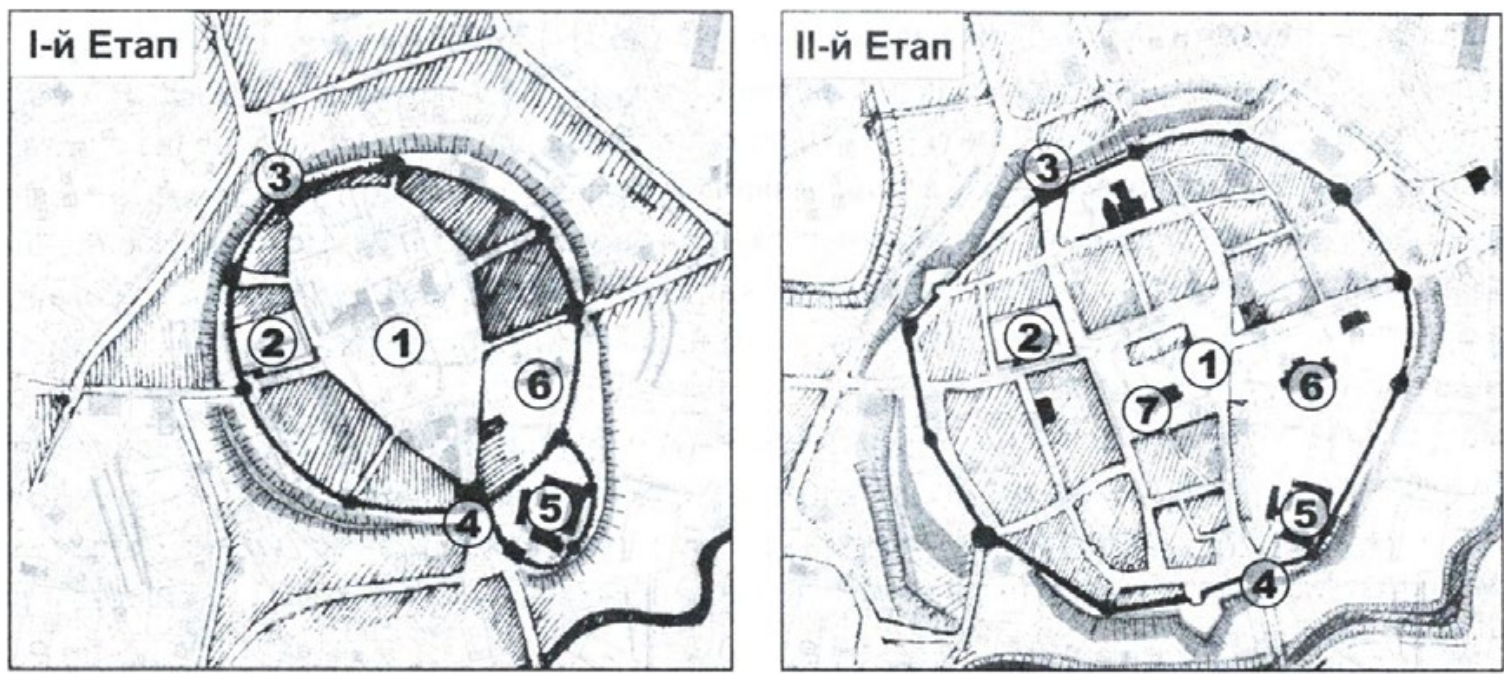

Fig. 4. Hypothetical reconstruction of two stages of development of planning structure of town of Rohatyn (at the end of XIV and at the beginning of XVII centuries) by M. Yasinskyi under the direction of O. Rybchynskyi [M. Yasinskyi, 2013]. 
According to the results of the analysis of historical works, the development of defensive structures of Rohatyn can loosely be divided into four main stages. For each stage, we implemented a hypothetical scheme of the planning structure of defensive lines.

First stage 1415-1509. From the very beginning, the middle town had a rectangular market square and a rectangular outline of the quarters around it. This rectangular planning scheme of quarters and streets surrounding the market square has survived to this day. The fortification girdle around the middle town repeated this rectangular planning scheme of quarters, encircling the middle area with a rampart along the perimeter. The argument proving our hypothesis is that already in the location privilege of the town the moats around the middle town were mentioned, from which "town's grounds were to be measured" [Tsariova N., 1995].

Construction of the defensive rampart at the beginning of the $15^{\text {th }}$ century should have been - in our opinion - of a basteja type (in German - Bastei, in Italian - Bastia, in Polish and Ukrainian - Basteja: a squat fortification, designed for the use of firearms, whose shape and placement were associated with the development of siege artillery. A small form of semicircular and multifaceted shape was erected forward of the curtain of the defensive wall to defend it against a flank fire. The first bastejas appeared at the end of the $14^{\text {th }}$ century with the commencement of the use of firearms. The using of bastejas is well described by Albrecht Durer [https:// de.wikipedia.org/wiki/Bastei]).

Due to the small size of the middle town, bastejas could only have been arranged in the corners of the defense perimeter. The shape of the bastejas was either rectangular or semi-circular (polygonal) in the plan. The fortification consisted of a low rampart, on the top of which there was a wall built of wooden logs a little higher than the height of a person. At certain intervals in the wall openings for the fire of small arms were cut. Externally, the rampart was surrounded by a moat. This form was typical of the wooden and ground fortifications in the $15^{\text {th }}$ century. Such fortifications were called the battle fence [J. Naronowicz-Naroniski, 1659] (fig. 5-a). The wooden fence as the fortification of Rohatyn was mentioned somewhat later, in 1509, in documents related to the storming of the town by the Wallachian-Turkish troops [A. Czołowski, 1930]. Since we do not have any historical mentioning of masonry walls at this time, it is logical to assume the existence of such wooden and ground fortifications.

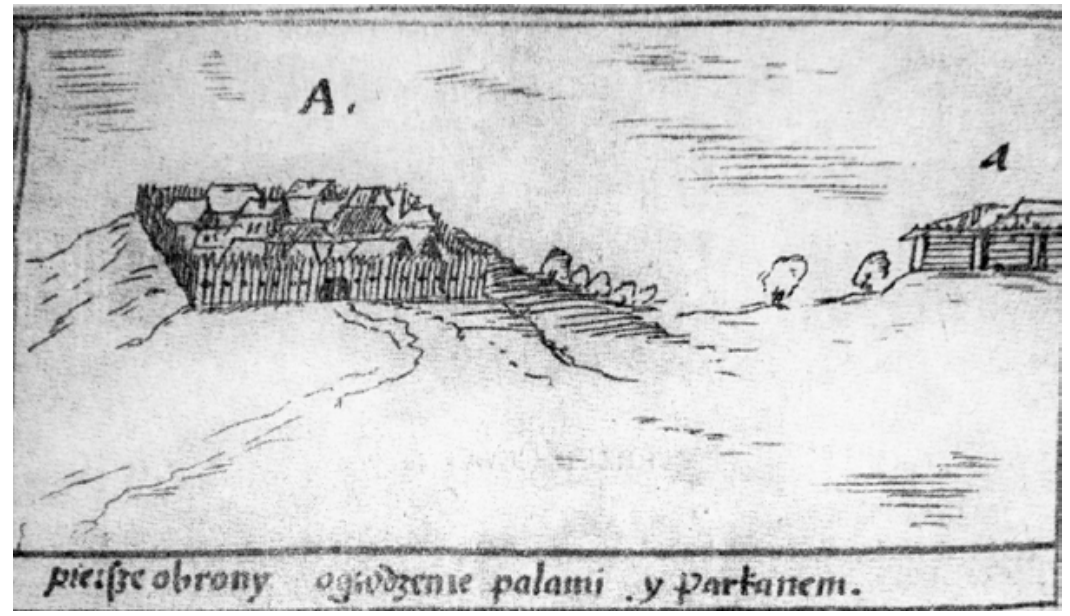

Fig. 5. Two old types of defensive walls of the city, which were built using wooden logs and piles: A - fortifications from sharpened, vertically dug piles; It was built on the top of an earthen rampart (socalled "Tyn"); a - fortifications from horizontal logs and piles (so-called "Fence"); as a rule had loopholes and roof; was built on the top of the earthen rampart (from the treatise by J. Naronowicz-Naroniski, 1659 [J. Naronowicz-Naroniski, 2016, s. 12]).

The use of this type of fortifications is confirmed also by the layout of the middle town (see schemes in Fig. 3, 4). Separate elements of such fortifications could be masonry - for example, gates, towers or bastejas. However, we think that there were no towers erected in Rohatyn, since it was irrational to build them from wood at that time as the enemy artillery could easily destroy them. As for the architecture of the gates, despite the fact that there are no direct references to the material from which they were erected, one can assume that they were made from stones and bricks. The masonry type of gates would also be more suitable for building a draw bridge. We know from the analysis by the historian A. Czołowski that during the siege of the town in 1509 it did not have sufficient means for defense. He mentioned only the wooden battle fence on the ramparts and the gates with draw bridges [Czołowski A., 1930]. In fig. 6, we present our hypothetical version of 
the planning structure of the middle town and its defensive girdle at the time after the town was founded in 1415. The main argument in favor of our scheme is the presence of an original rectangular planning structure in the middle of the town.

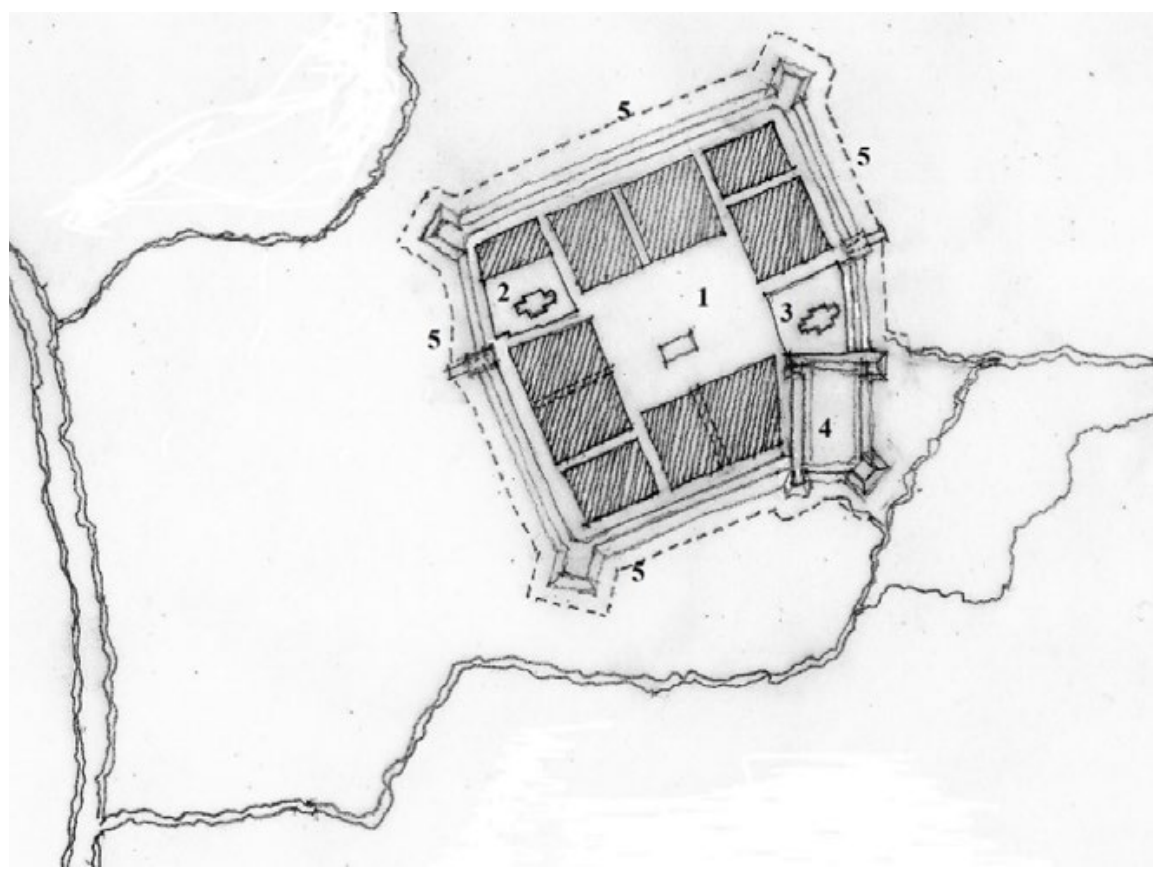

Fig. 6. Hypothetical scheme of the planning structure of the Middle town and its defensive zone at the period 1415 and to 1509 (by M. Bevz). Marked: 1 - market square, 2 - Tserkva of the Nativity of the Virgin Mary Mary, 3 - wooden church of St. Mykola, 4 - castle, 5 - defensive shaft with wooden palisade (tyn) with corner towers and two gates. Author: M. Bevz, 2017.

The second period 1509-1550s. The key events for Rohatyn of 1509 will be presented on the basis of thorough research by Alexander Czołowski ("Rohatyn's Catastrophe in 1509 Historical Sketch" [Czołowski A., 1930, 15 s.]). The historian briefly described the events of the Wallachian-Turkish-Polish War of 1509, but the events related to the town of Rohatyn he considered in sufficient detail.

The basis of the war was clearly the territorial claims of Turkey, which provoked the conflict through their vassals. Events unfolded as follows. The Voivode of Moldavia, Bogdan, having collected a military force from the Wallachians, Tatars and Turks, decided to raid Pokuttya. The king of Poland, Zygmunt I, issued an order to raise militia on August 1 in Horodok near Lviv, but this reaction was too late. The main goal of Bogdan was to capture the castle of Halych and to secure Pokuttya and a part of Podillia. With considerable strength, he conceived the attack not as a small strike, but as a broad military campaign. In mid-June, his troops crossed the Dnister River near Khotyn and on June 17 they reached Kamyanets-Podilsky. However, without being able to lay a long siege to the impregnable and well-fortified castle and town, he withdrew the unsuccessful siege and went deep into Rus. Over the course of several days, the troops besieged the cities of Pokuttya - Sniatyn, Kolomyia, Tlumach, Cheshybisy (Yezupil) - and subsequently also the Castle of Halych [Czołowski A., 1930].

The castle of Halych, the defense of which was led by starosta Otto Chodecki, managed to prepare for the siege. In addition, its high location did not allow the Wallachian troops to effectively bombard its towers and walls with artillery. Moreover, an active way of defense and counterattack against the attackers allowed the starosta to even capture a part of the artillery, which was unwisely brought closer for the bombardment of the castle. Forced to leave the siege, Bogdan, ruining everything on his way, went through Khodoriv to Lviv and on July 1 stood under the walls of the town. Having burned the Gothic Catholic Church of St. Stanislav in the Krakowian Suburb, he began the bombardment of the Low Castle and the middle town from the territory near it [Czołowski A., 1930]. But his efforts were useless here as well. The town defended itself successfully and also counterattacked, as a result of which Bogdan's troops suffered considerable losses. Inability to capture the town and knowing about the approach of the militia from Horodok, the Voivode retreated, burning to the ground the Halychian and the Krakowian suburbs. He marched his forces along the road to the south-east to the crossing across the Dnister River near Cheshybisy. 


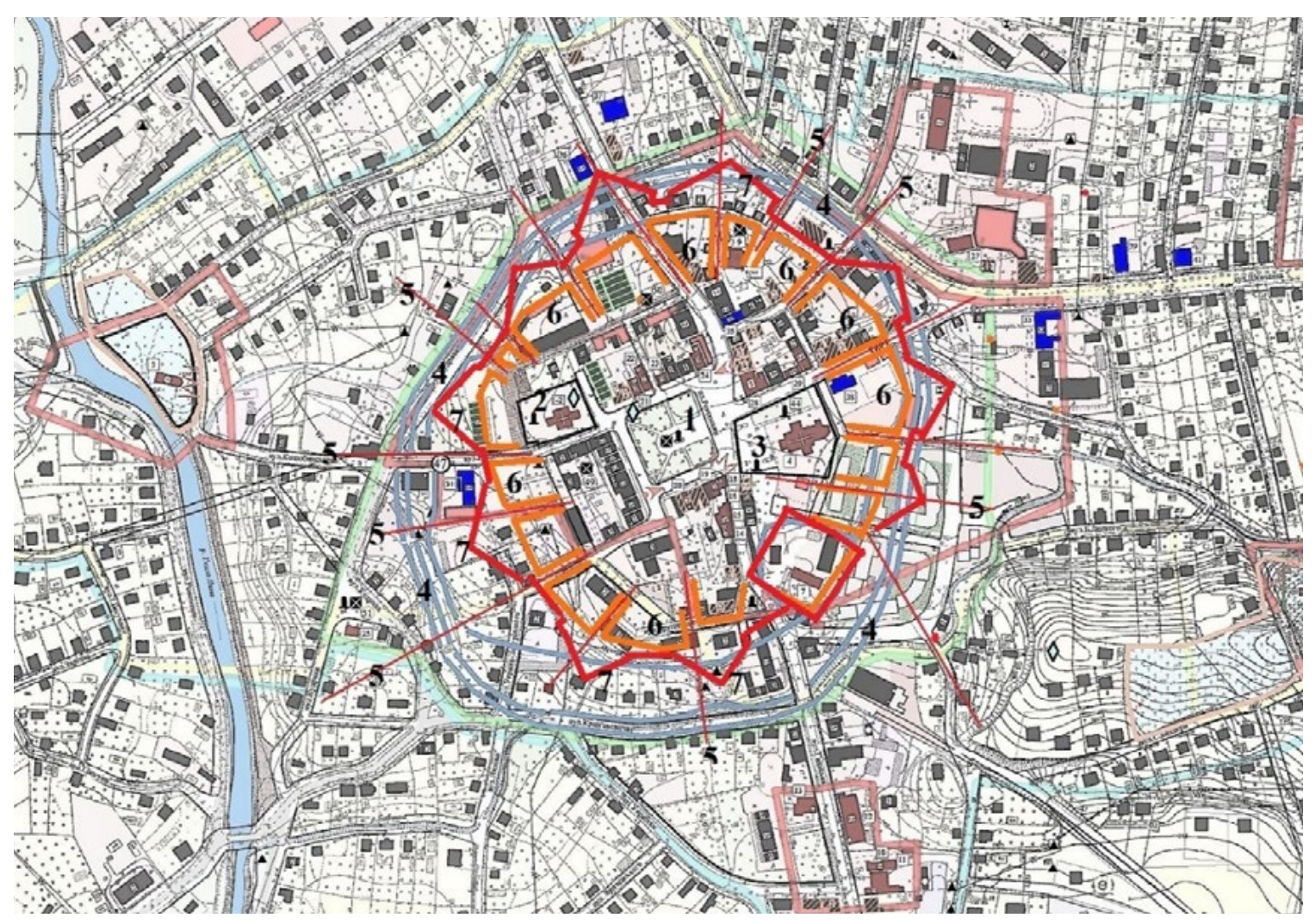

Fig. 7. Scheme of elements of planning structure of center of Rohatyn, indicating a change in the concept of its development at the beginning of the $16^{\text {th }}$ century (reconstruction of the destroyed town after the devastating attack of 1509). There are streets of a radial nature in relation to the Rynok Square (pos.5), the configuration of the quarters varies from rectangular to irregular forms (item 6), a hypothetical line of "defensive fence" on new shafts (item 7). It is also marked: 1 - Rynok Square, 2 - Tserkva of the Nativity of the Virgin Mary, 3 - St. Nicholas Church, 4 - lines of defensive fortifications according to the plan of UDNPI "Dipromisto", 5 - radial character of the axes of new streets. Author: M. Bevz, 2017.

Rohatyn stood on the enemy's road. At that time it was one of the richest towns in Rus'. Historian A. Czołowski pointed out that the town was very successful in trade and crafts [Czołowski A., 1930, p. 3]. The town, which was founded in 1415, was planned according to the requirements of the Magdeburg Law, and was fortified with ramparts and a moat around the middle town. At the end of the $15^{\text {th }}$ - in the beginning of the $17^{\text {th }}$ century, the town was owned by the wealthy Chodecki family. The middle town of Rohatyn "was well built, surrounded by a rampart with a fence through which the defensive gates led" [Czołowski A., 1930, p. 5].

Here it is necessary to make a refinement to the version of A. Czołowski - the so-called battle fence in the $15^{\text {th }}-16^{\text {th }}$ centuries was built from rough wooden logs with slits for firearms. The method of building fortifications from the lines of a wooden fence at the top of the rampart was called "tyn". The name of the town indicates that perhaps the most oldest way of strengthening the town was the rampart-tyn (Roha-tyn) technique. It presupposed the construction of deep-drawn vertical pillars.

New tipe "parkan" presupposed the construction of deep-drawn vertical pillars at intervals of several meters only, between which the logs were laid horizontally. In the logs, at the height of a person, cut-outs were made. From the outside, the rampart with a fence has a moat with a breastwork (made of clay and soil, sometimes of wooden logs). For artillery, somewhat elevated positions in the form of triangular or polygonal bastejas were made at some intervals in the line of fence fortifications. Their construction was carried out in the same way. Inside of such ramparts behind the fence was located the middle town of Rohatyn, and the defensive castle of the owners that was connected with it. Inside, behind the town fortifications were also two masonry shrines. The oldest was the town Tserkva of the Nativity of the Virgin Mary Mary, built by the Presluzhych in the Byzantine-Gothic style and the catholic church of St. Nicholas (the original was erected in 1440 by Mikołaj Parawa from Chodcz [Czołowski A., 1930, p. 6]). The church bell tower had the largest bell in Rus'. 

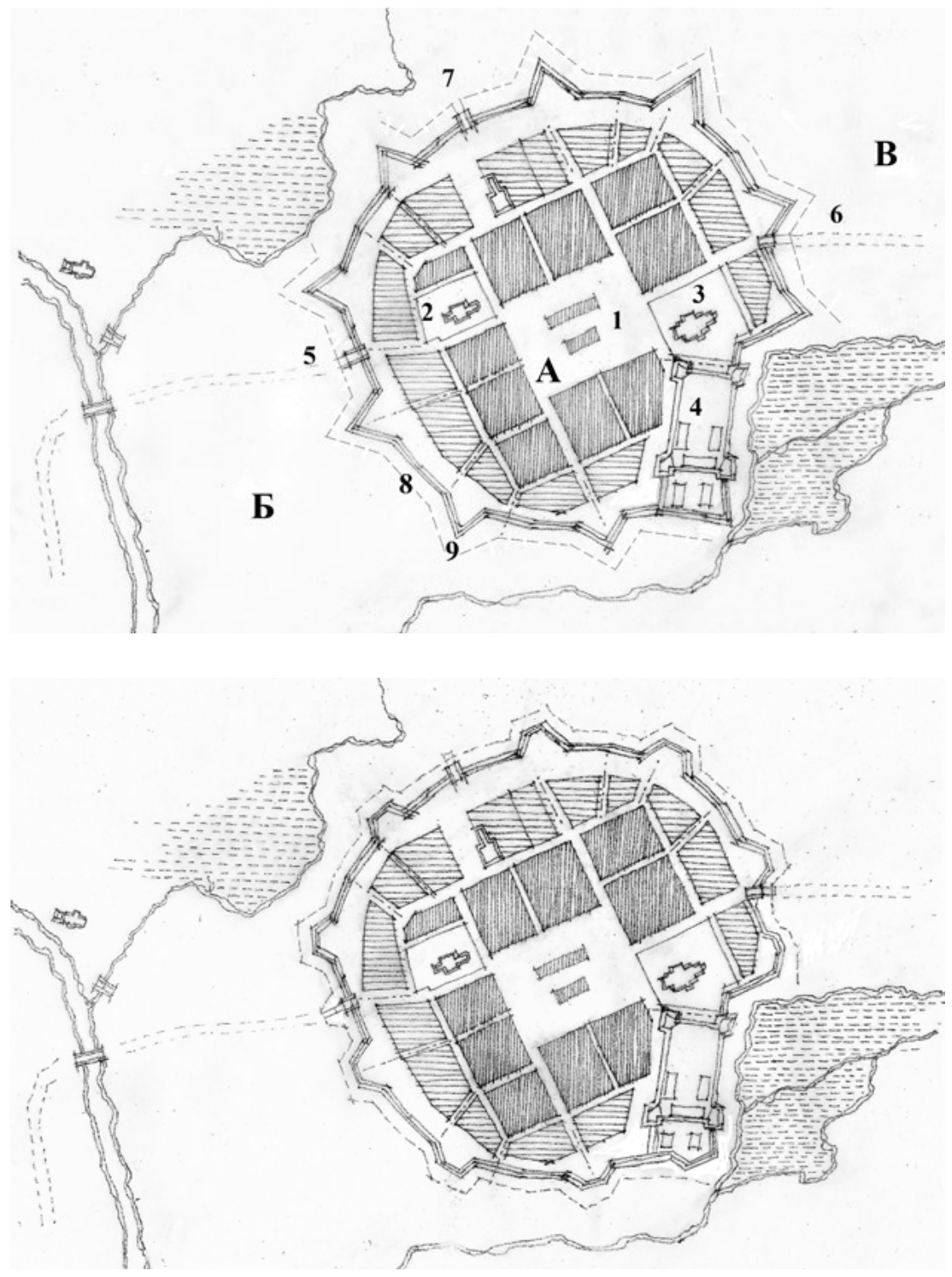

Fig. 8. Hypothetical reconstruction of the scheme of fortifications of Rohatyn at the middle of the $16^{\text {th }}$ century. Marked: $A$ - the middle town; B-Halytske suburb; B - Babintsy suburb; 1 - Rynok Square, 2 - Tserkva of the Nativity of the Virgin Mary, 3 - St. Nicholas Church, 4 - Castle, 5 - Halych Gate, 6 - Berezhany Gate, 7 Lviv Gate, 8 - Curtain Wall of the Defensive Wooden Fence, 9 - Triangular wooden bastejas (bastei) of a defensive fence; Vertical strokes mark the original quarters of the $15^{\text {th }}$ century; Quarters of the $16^{\text {th }}$ century are marked with horizontal strokes. Author: M. Bevz, 2017.

Fig. 8a. Hypothetical reconstruction of the scheme of fortifications of Rohatyn at the middle of the $16^{\text {th }}$ century. Second version based on polygonal bastejas.

On July 6, 1509, the Moldovan Voivode began the siege of the town. Though the town had the fortifications described above, they did not give hopes for a long-term defense. The enemy had artillery for the siege, and the town did not have enough defenders. Two owners of the town - Rafal and Piotr Chodecki- were in the castle and nevertheless organized the defense. The inhabitants endured the first hostile assaults. But the artillery bombardments and the prevailing enemy forces put the defenders into an uneasy situation. After a few days of defense, the owners, understanding the hopelessness of the situation, decided to surrender and opened the gates of the town. As a result, the attackers mercilessly robbed the town, and Bogdan appropriated the treasures of the two churches, jewels and liturgical utensils, including the bells. The town was completely burned down, and all the inhabitants were captured. Shrines were also burned. In one day, Rohatyn was turned into a deserted, scorched ruin. It is this attack with which the legendary story of Roxelana (Anastasia Lisows$\mathrm{ka}$, daughter of a local priest, later known as the wife of Suleiman the Magnificent, the Sultan of the Ottoman Empire [https://uk.wikipedia.org/wiki/Rogatin]) is associated.

Only a month and a half later, in September, militia was gathered near Hlyniany (in Vyzhniany) for a campaign and revenge for the Wallachian-Turkish attack. This trip to Wallachia ended with a complete victory and captivity of more than thirty Wallachian nobles. In November, the war was completed by the signing of a peace treaty, which envisaged the return of all the looted property to Rohatyn, release of captives and granted them 
the right to return to the town. Only the eldest of the Chodecki brothers, Rafal, returned to Rohatyn, whereas Piotr died in captivity [Czołowski A., 1930, p. 6].

Upon his return, Rafal started the restoration of the town. This reconstruction probably lasted more than a decade. The relative of the owners - Halychian starosta Otto from Chodecz (Chodecki) - actively participated in it. His military experience was probably used to rebuild the old and to build new fortifications. In 1523 , the owner of the town gave permission to hold a weekly meat trade in Rohatyn each Saturday from Easter to Baptism of St. John (June 24) [Balinski M., 1844, p. 702-703]. This privilege allowed to increase the town's profits and to use the funds to improve its defense capability.

In 1533, Otto Chodecki made the town over to the King [Besiadecki F., 1936, p. 2]. In 1534, the town formally became the king's property. According to the decision of Zygmunt I, in 1535, Rohatyn received a new confirmatory locational privilege, the right to a weekly public market and a coat of arms (a reindeer horn and letter "B") [J.S. Zubrzycki, 1914]. At that time, it was starosta Ivan Boratynsky who administered the affairs of the town. This event served as the basis for the rapid development of the town, which soon began to compete with Lviv [https://uk.wikipedia.org/ wiki/Рогатин].

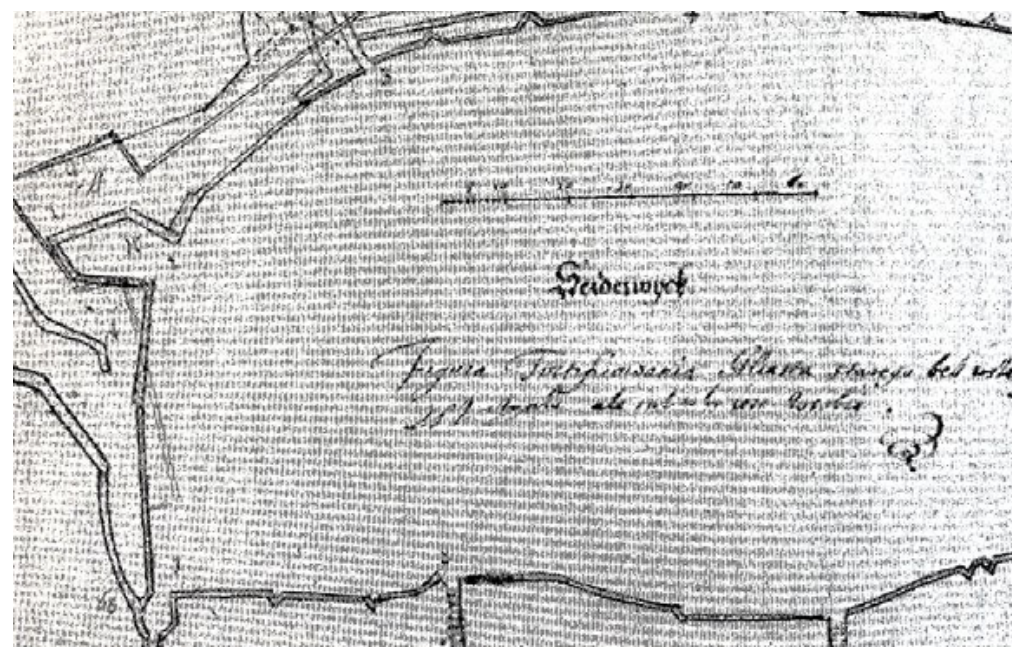

Fig. 9. Example of modernization projects for the fortifications of the old town of Herderwyck in the Netherlands, early $17^{\text {th }}$ century. The old line of fortifications, consisting of a triangular bastejas, is replaced by a bastion line. On separate sites, the old belt of fortifications had two parallel lines of bastejas with triangular base. The distance between the bastejas was between 10 and 20 Dutch rods, which equals to $46.23-92.46 \mathrm{~m}$. There are 6 variants of a more perfect configuration of a new bastion line, which is planned not on the site of the old fortifications, but creating a new line from the outside (an illustration from the book of J. Naronowicz-Naronski, 1659 [J. Naronowicz-Naronski, 2016; p. 124]).

As part of the privilege of 1535, king Zygmunt I exempted the town from a part of their tax obligation forever; allowed people to cut trees in the forests, so that they could be used for the needs of the town; and imposed a one-year tax on the production of alcohol, as well as a one-year tax on immovable property, proceeds from which were used for the construction of fortifications. The privilege included the following words: "... considering the fact that the town is exposed to frequent hostile attacks and was destroyed several times, we impose a one-year tax on the production of alcohol, as well as a one-year tax on immovable property, called 'szos', proceeds from which will be used (for the construction) of fortifications" [Balinski M., 1844, p. 703].

This served as an impetus for the construction of new fortifications. A defensive line consisting of a rampart and a fence on it, which encircled the middle town, was restored. The rampart had a moat from the outside, and there were bastejas located a small distance from each other; the rampart encircled the middle town along a closed perimeter (Fig. 8, 9, 10). This new defensive girdle differed significantly from the previous one in terms of configuration. The middle town became bigger and received a so-called star-shaped fortification girdle with a rampart and a fence with bastions (Fig. 11).

Fortifications of the neighboring town of Berezhany, where Old and New Town were surrounded by a rampart with a wooden fence and triangular and five-pointed bastejas, were made in a similar way [Kuśnierż K., 1984 , p. 54]. In Berezhany this girdle of fortifications was built in the 1580s. At that time, defensive lines consisting of a rampart, a fence, and bastejas were built in other towns of Western Ukraine as well, for example, in Uhniv, Belz, Olesko, Olyka, etc. Fortifications in Lviv were also built in this way, forming the third defensive girdle around the middle town with bastejas and beluards. Here, however, an earth rampart and bastejas were surrounded by a masonry wall. 


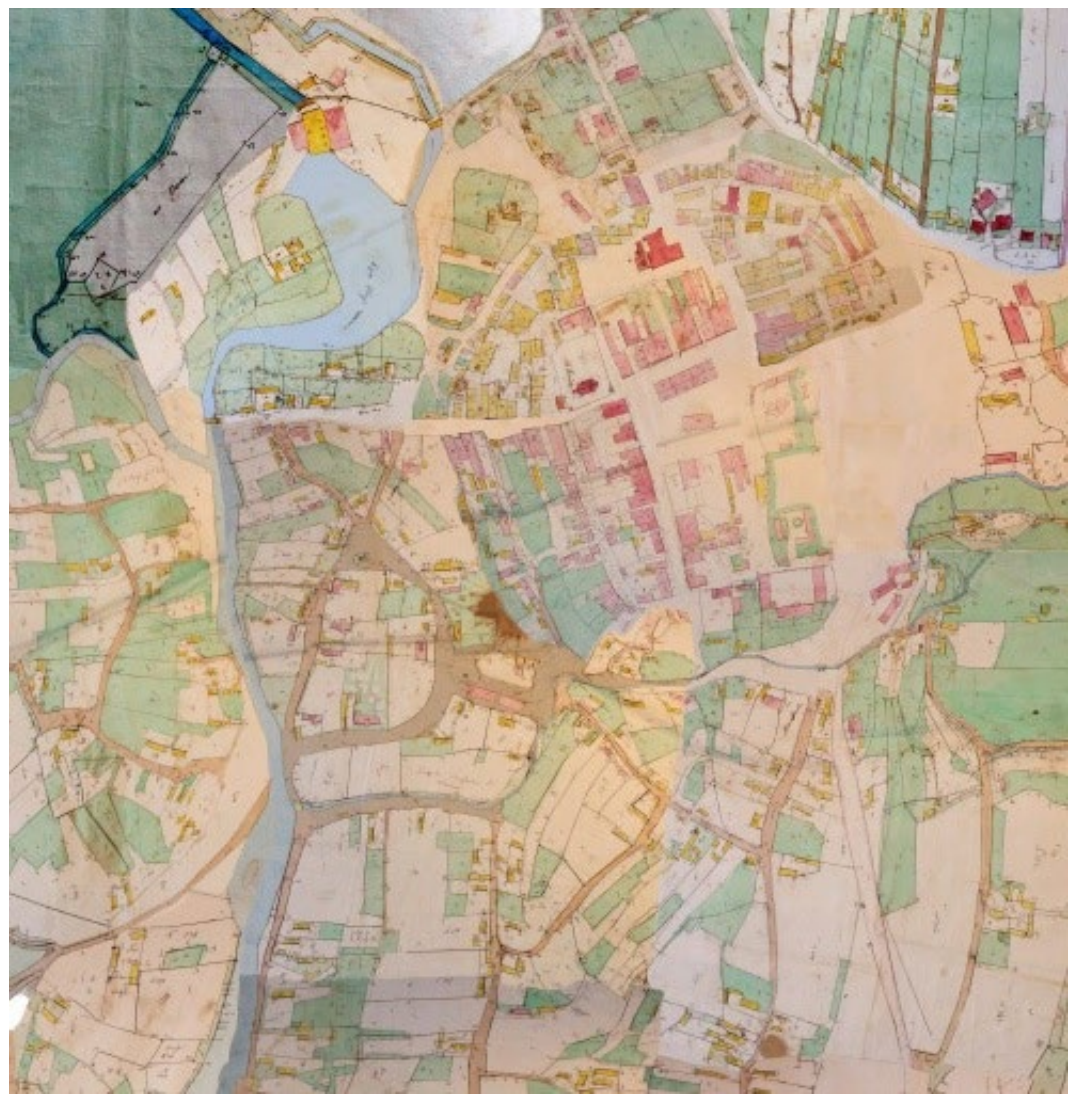

Fig. 10. Handwritten Plan of Rohatyn; 1846 (Central State Historical Archive of Ukraine in the city of Lviv). The consolidated version of the plan [http://rohatynjewishheritage.org/en/maps/1846-cadastral].

It took several years to increase defense capability of Rohatyn. A new privilege granted by Kng Zygmunt I in 1539, proclaimed "in order for the town to grow, and so that it can be surrounded by walls, we allow people to build a town hall and a building for cutting broadcloth on the market, the proceeds from which, as well as the proceeds from vodka, shall be used for maintaining town fortifications in proper condition" [BalinskiM., 1844]. The privilege explicitly declared the need to build more powerful masonry fortifications: "in order for the town to grow, and so that it can be surrounded by walls..." [Balinski M., 1844].

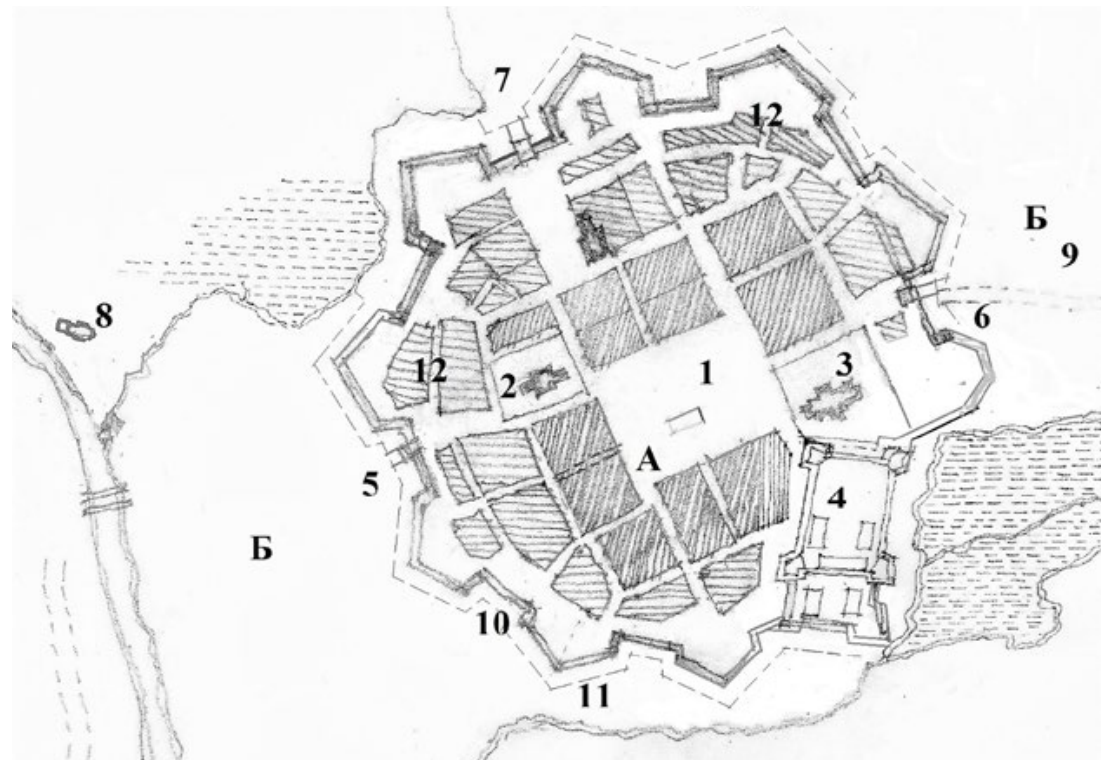

Fig. 11. Hypothetical reconstruction of the scheme of fortifications of Rohatyn at the end of the $16^{\text {th }}-$ early $17^{\text {th }}$ century. A - the middle town; Б - suburbs; 1 - Rynok (Market) Square, 2 - Tserkva of the Nativity of the Virgin Mary, 3 - St. Nicholas Church, 4 - castle, 5 - Halych gate, 6 - Berezhany Gate, 7 - Lviv Gate, 8 - Tserkva of the Holy Spirit in the western suburbs, 9 - St. Barbara church in the eastern suburb. 10-11 bastion fortifications; 12 - area of buildings "On the shafts", a new district of the middle town created with the construction of the new plan of fortifiacations. Author: M. Bevz, 2017. 
Therefore, creation of masonry fortifications in place of wooden fortifications in Rohatyn should be associated with the decades following 1539. At that time, the town was part of the kingdom, so it is logical that it is the starosta who had to supervise the works, and one of the court engineers or architects of King Zygmunt I the Old had to be a draftsman of the new fortifications. What was the nature these new fortifications? Was the path of modernization of old earth and wooden fortifications selected, or was a completely new line erected? Regardless of privileges and benefits, financing available to the town was not too great.

At that time, fortifications were built in many other cities of the Polish-Lithuanian State. The tradition of constructing fortification lines consisting of bastejas and proto-bastions dominated. Such a fortification was often a combination of masonry and earth construction. They were made in the form of straight sections of a rampart with a moat, surrounded by a masonry wall from the outside. Semicircular masonry bastejas with battlements were erected at small intervals on a rampart, where positions for artillery were arranged. In particular, such a technique was used in Lviv when creating the third defensive line, which, besides bastejas, consisted of several large beluards and the Gunpowder Tower. Fortifications in other cities - Baranów Sandomierski, Berezhany, Brody- were built similarly. However, we also know another tradition - masonry walls with galleries for marksmen and round towers were built in Zhovkva at the end of the $16^{\text {th }}$ century. The so-called Low Defense Wall layout, which was popular in the $15^{\text {th }}$ century, was used here. It was used in Halychyna until the beginning of the $17^{\text {th }}$ century. It was especially popular when building fortifications of monasteries and castles.

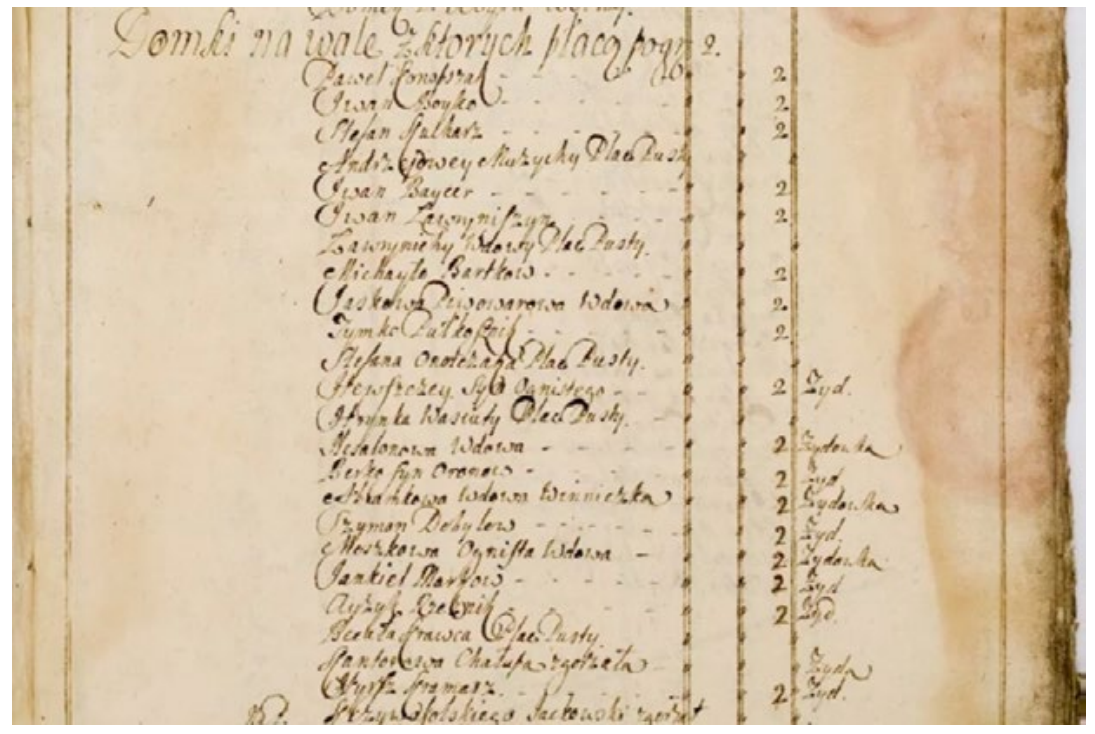

Fig. 12. The Lustration from 1765 with the list of owners of houses in the district "On the ramparts" [https:// get.google.com/album archive/104519598602010189193/ album/].

In our opinion, there were prerequisites for the use of the fortifications consisting of bastejas in Rohatyn at the beginning of the $16^{\text {th }}$ century, which was later - at the end of the $16^{\text {th }}$ - in the first half of the $17^{\text {th }}$ century - transformed into fortifications consisting of bastions. Such a layout was easy to achieve, by modernizing previous fortifications consisting of a rampart and a fence. The type of fortifications in the form of a rampart with a fence was used in our cities for quite a long time. In the picture of the middle town of Bolekhiv dated 1607 we see this exact type of fortifications. We also know from the history of Zhovkva that in the early $17^{\text {th }}$ century, Lvivske and Hlynske suburbs had similar fortifications with a wooden-earth fence [M. Bevz, 2002].

Modernization of the new defensive girdle around the middle town took a long time. This is evidenced by the register dated 1572. According to the privilege of 1539, it was planned to erect masonry fortifications for the middle town, but this is mentioned in the document dated 1572 in the following form: "the old town is surrounded by a fence". This information can be understood in such a way that the wooden fence was completely replaced by a masonry one, without changing the configuration of the defensive girdle significantly, which allowed the registrar to continue to call it a fence. Such an option, in our opinion, was quite possible. According to another version, this name can be explained by the fact that works were preformed slowly and some part of the fortifications still had the form of a wooden fence. It is logical to assume that, first and foremost, the 
works were performed at the gates and bastejas which had to be adapted to the new artillery weapons. For some time, curtain walls could still be in the form of an old wooden fence.

In Rohatyn we still have an example of such a low defensive wall with loopholes in the form of a keyhole, which surrounds the territory of the Tserkva of the Nativity of the Virgin Mary. It is quite possible that this wall is not authentic and was erected in the $18^{\text {th }}$ century using the material obtained when dismantling fortifications. But in any case, stone blocks with loopholes in the form of a keyhole are elements of masonry defensive walls and direct evidence of the fact that such fortifications existed in Rohatyn.

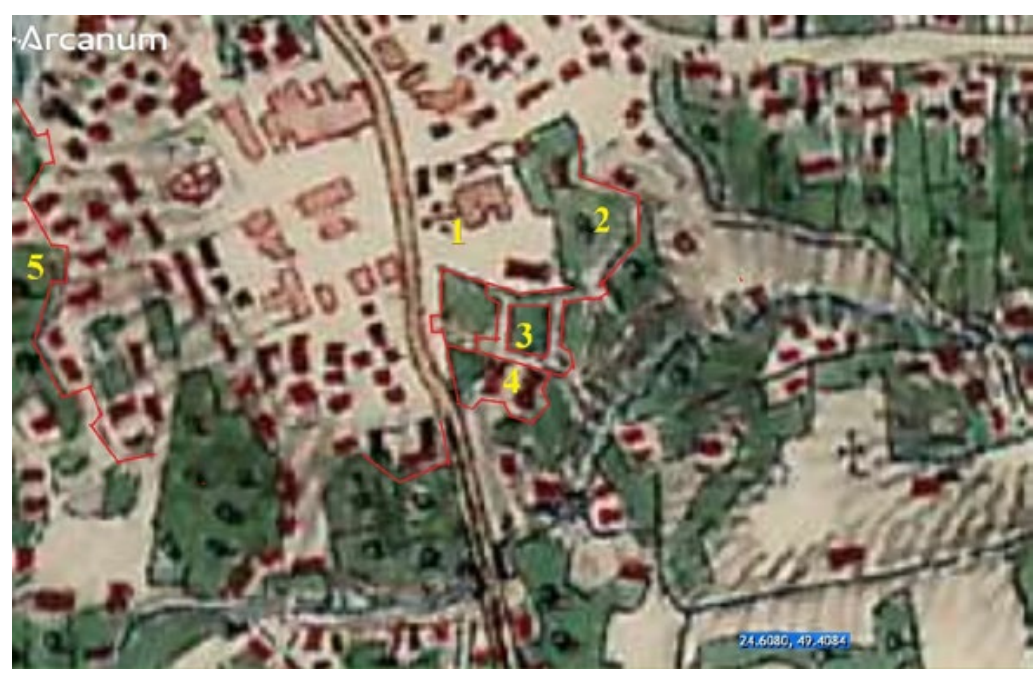

Fig. 13. The plan of the town of Rohatyn on the Austrian map of the $2^{\text {nd }}$ Military Description of Galicia (Halychyna) since 1861 ([http://mapire. eu/en/map/ second survey / 1861]); using lines we marked the remains of shafts on the plan. We marked also: 1 - the church of St. Nicholas, 2 trapezoidal bastion near the church, 3 - the upper court of the castle is surrounded by a shaft with bastejas, 4 - the lower courtyard of the castle had bastions, 5 - the remains of the shafts of the western bastion line. To the south-west of the middle town is a large rectangular new market square, located in the "New Town" district.

We believe that the preserved defensive wall near the church must be studied in more detail, and its elements should be an example for reconstructing lines of fortifications in the middle town at the end of the $16^{\text {th }}$ century. J.S. Zubrzycki pointed out that Lviv and Halych gates lasted until the end of the $17^{\text {th }}$ century. He also stated that there were several suburbs in Rohatyn in the $16^{\text {th }}$ century - Babyntsi, Zavoda, Na Vulytsyakh, New Town - without going into detail about their location and role in the system of town fortifications.

According to the register dated 1572, 115 bourgeois (courtyards) and 18 storekeepers resided in the Old Town surrounded by a defensive fence [Slownik, 1888, p. 693]. The record from the register about the fact that there were 36 more houses in the "On the Rampart" district is very important. In our opinion, this fact shows that lines of fortifications in the middle town were expanded, forming a completely new line. "On the Rampart" district emerged in place of the "old rampart". In our opinion, five-pointed bastions were erected for the new line. Fortifications were modernized gradually, and in 1572 , there were probably still old fortifications consisting of a rampart and a fence in a considerable part of the middle town.

In the town, in addition to the parochial St. Nicholas Church, there was also catholic St. Barbara Church, two masonry churches and two wooden churches, the Dominican monastery, a monastery of sisters from the Order of Saint Basil the Great (it was later transferred to Slovita in 1769) [Besiadecki F., 1936, p. 3]. There were 8 guilds in the town. Somewhere at the end of the $16^{\text {th }}$ century, migration of Jews from Silesia, Poland, and Hungary to Halychyna began, and a Jewish community was formed in Rohatyn [https://uk.wikipedia.org/wiki/Рогатин].

In addition to the record about the "On the Rampart" district, records about the Old and New Towns are also very important when speaking about the register dated 1572. The record indicates that the town was already expanded as at 1572 . Along with the old fortified urban complex, a new one (the new town) emerged, which logically also had defensive structures. According to the data contained in the register, there were 100 courtyards and 11 storekeepers in the New Town [Slownik..., 1888]. This means that this district was not smaller than the middle town, where 115 courtyards were recorded. 


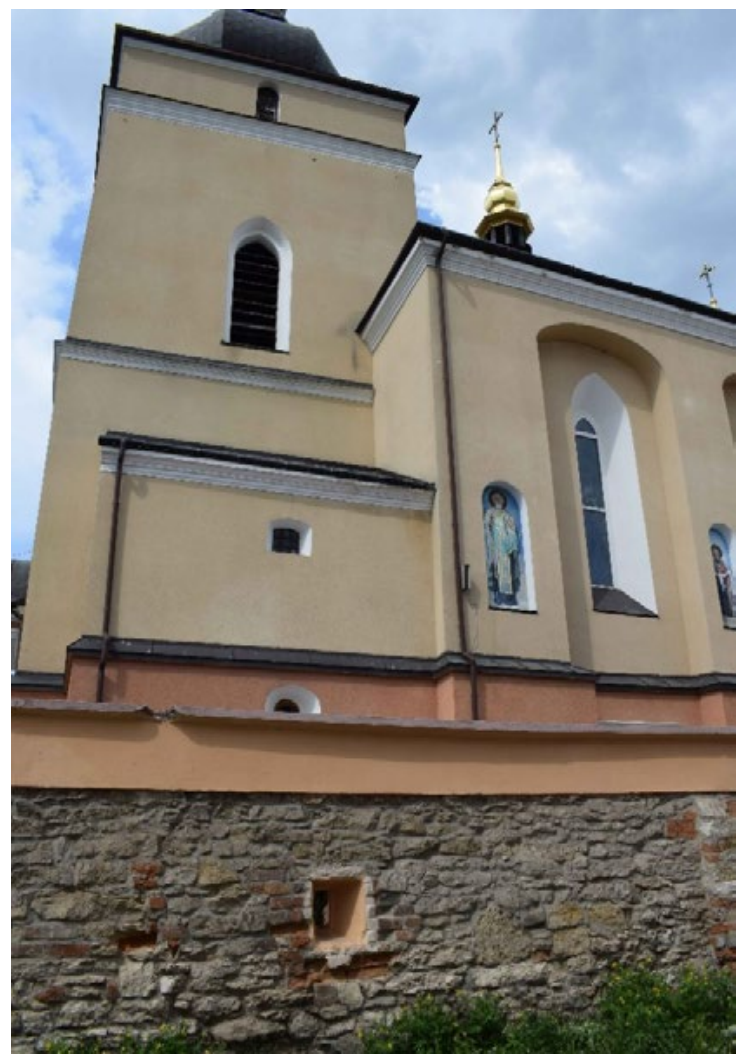

Fig. 14. Photo of the defensive wall around the Tserkva of the Nativity of the Virgin Mary in Rohatyn with a loopholes for muskets, which are arranged with an interval of 6-7 $\mathrm{m}$.

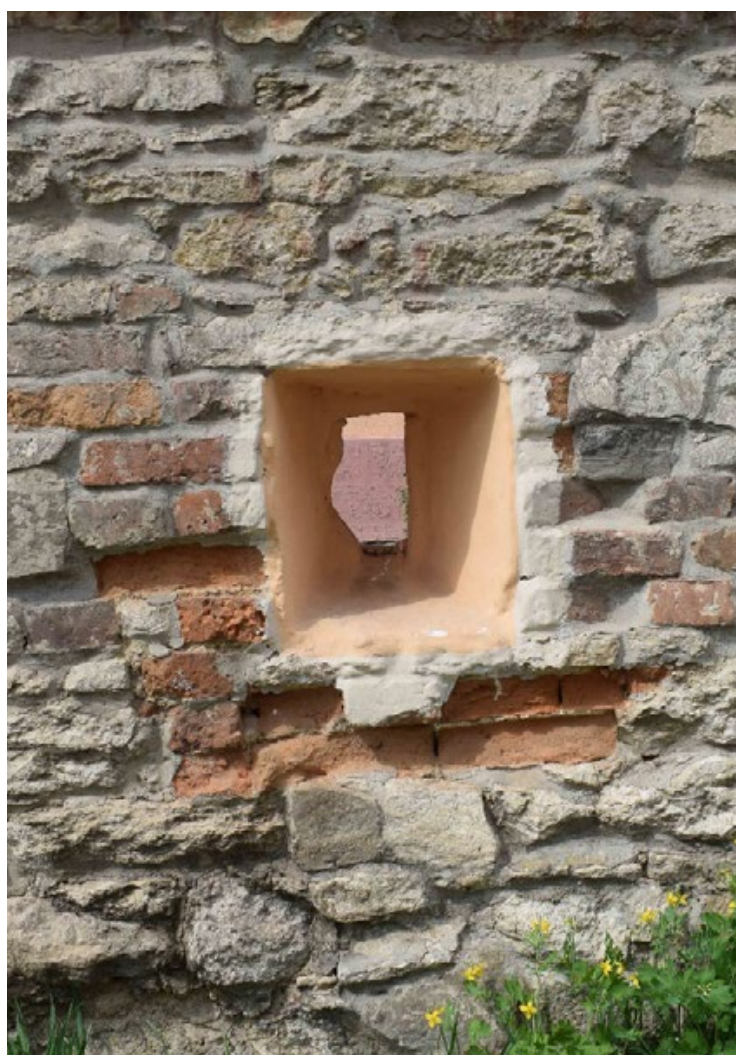

Fig. 15. Photo of a fragment of the defensive wall of the Tserkva of the Nativity of the Virgin Mary in Rohatyn with a key loophole for muskets. Bricks in the wall have dimensions characteristic for the beginning of the $17^{\text {th }}$ century.

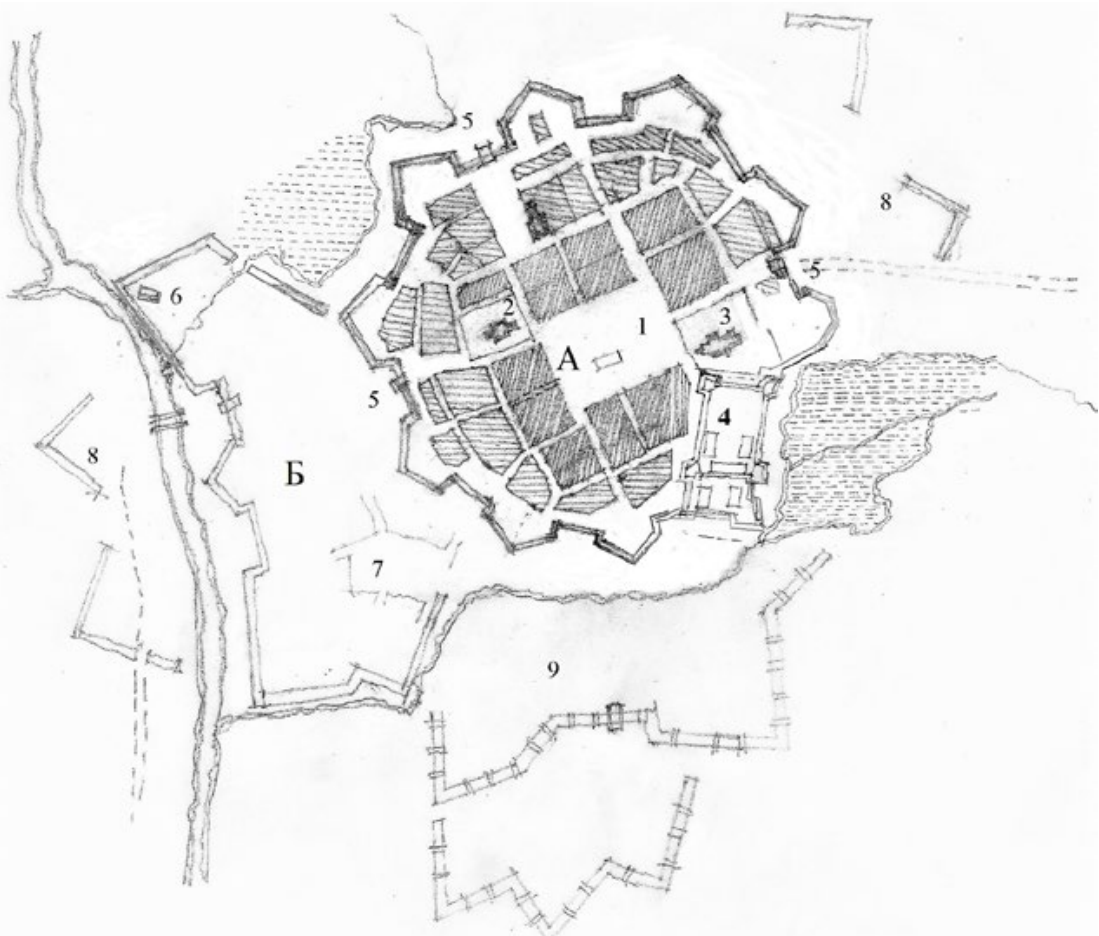

Fig. 16. Hypothetical reconstruction of the scheme of fortifications of Rohatyn at the $17^{\text {th }}$ century. Marked: A the Old Town; $\mathrm{B}$ - New Town; 1 - Rynok Square, 2 - Tserkva of the Nativity of the Virgin Mary, 3 - St. Nicholas Church, 4 - castle, 5 - Halych and Lviv gates, 6 - Wooden tserkva of St. Spirit in the New Town, 7 trade square in the New Town, 8 - hypothetical external shafts on the approaches to the town, 9 - a hypothetical scheme of a line of fortifications since the beginning of the $17^{\text {th }}$ century. Author: M. Bevz, 2017. 
We should also emphasize this important feature of Rohatyn's urban development - between 1539 and 1572, a new district called the "New Town" emerged here. We identify this district with the territory located southwest of the middle town. We came across Novomiska (New Town) street a little to the west of the Tserkva of the Nativity of the Virgin Mary even on maps that date back to the beginning of the $19^{\text {th }}$ century [http:// www.rohatynrg.org/home/geography/townmaps/RohatynResearchGroup].

Our analysis of the planning structure of the New Town shows that there was also a line of fortifications along the perimeter of this district (Fig. 16). However, configuration of the lines of these fortifications clearly indicates the existence of bastions which were probably erected or reconstructed later, in the $17^{\text {th }}$ century. Circumstances of the emergence of this New Town, identification of its boundaries, and its development must still be studied in detail. When it comes to urban processes of the $16^{\text {th }}-17^{\text {th }}$ centuries, it was quite common to form new middle towns not far from the old ones and to even grant them individual privileges with regard to location in accordance with the Magdeburg Rights. Neighboring Berezhany (Fig. 17), where there were as many as three middle towns close to each other, each of which was formed in accordance with its own Magdeburg Rights, can serve as an example of this. Two of them were surrounded by a shared fortification bastion girdle [M. Bevz, 2000; K. Kuśnierz, 1984].

Thus, we can conclude that there was significant urban development in Rohatyn before 1572, a new town district was built, but it was not granted a separate self-governing status. Location of this new town is confirmed by historical documents. In particular, there is a reliable record of the New Town district dated 1616. In Fig. 16 we provide a hypothetical layout of the boundaries and fortifications of the New Town.

In the register dated 1663, there were 36 houses in the New Town and 6 wooden log cabins on the Ramparts [Slownik ..., 1888]. The latter is very interesting and important. First of all, it shows that there were ramparts in the New Town. There is no concrete information about these log cabins that were located on the ramparts, but it is important that they are connected to the ramparts. Therefore, we have arguments which confirm that the New Town district, just as the Old Town, was also surrounded by ramparts, and the aforementioned number of log cabins could be indicative of the number of bastions in the structure of the defensive girdle.

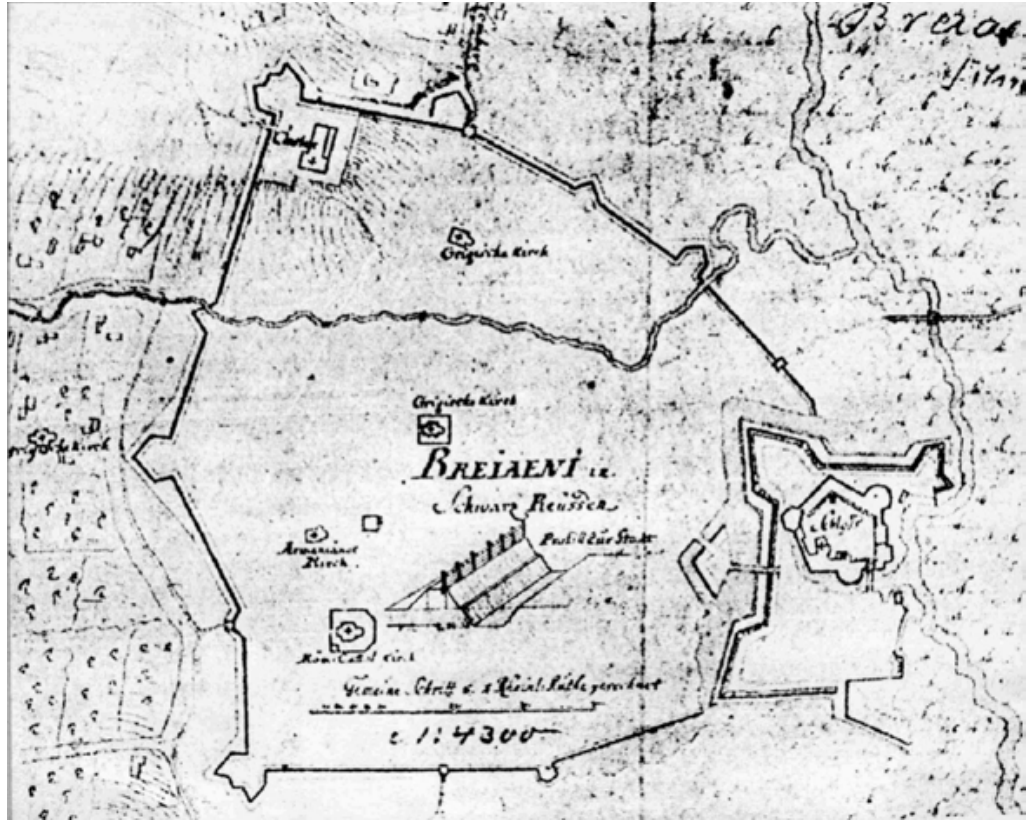

Fig. 17. The fortification of the town of Berezhany on the plan from 1720. In the center a fragment of the fortified line is drawn - a shaft with a wooden fence (according to K. Kuśnierz, 1984). The defensive line included triangular and pentagonal bastions.

In 1663, there were 140 courtyards in the old town, 31 courtyards in the new town, and 6 log cabins on the rampart. According to the register dated 1765, there were 301 households of bourgeois Christians and 125 households of bourgeois Jews in the old and new town [Slownik ... 1888, p. 694]. The register also listed several gypsum mines in the town. According to Jan Zubrzycki, in the $16^{\text {th }}-17^{\text {th }}$ centuries, Rohatyn was a wealthy and growing trading town. Such a characteristic may indicate that, first of all, the town was able to build and 
modernize the fortified system of the middle town, and, second of all, without good modern fortifications, the town was unlikely to succeed and develop as a mercantile and crafts center.

In August 1914, during the First World War, the suburbs of Rohatyn were almost completely destroyed, burned and ransacked by Russian troops. Photographs taken at that time convey the tragedy of the destruction of a well-built town. Near the wooden Church of the Descent of the Holy Spirit (the church is one of 16 sites that belong to the wooden sacral church architecture of the Carpathian region of Ukraine and Poland included in the UNESCO World Heritage List) there is a cemetery where Austrian soldiers who died in the First World War in battles in Rohatyn and on its suburbs are buried. During the Second World War, the central part of the town was ruined again; the Jewish district was burned almost completely. Nearly nine thousand of the town's Jewish population were killed [38].

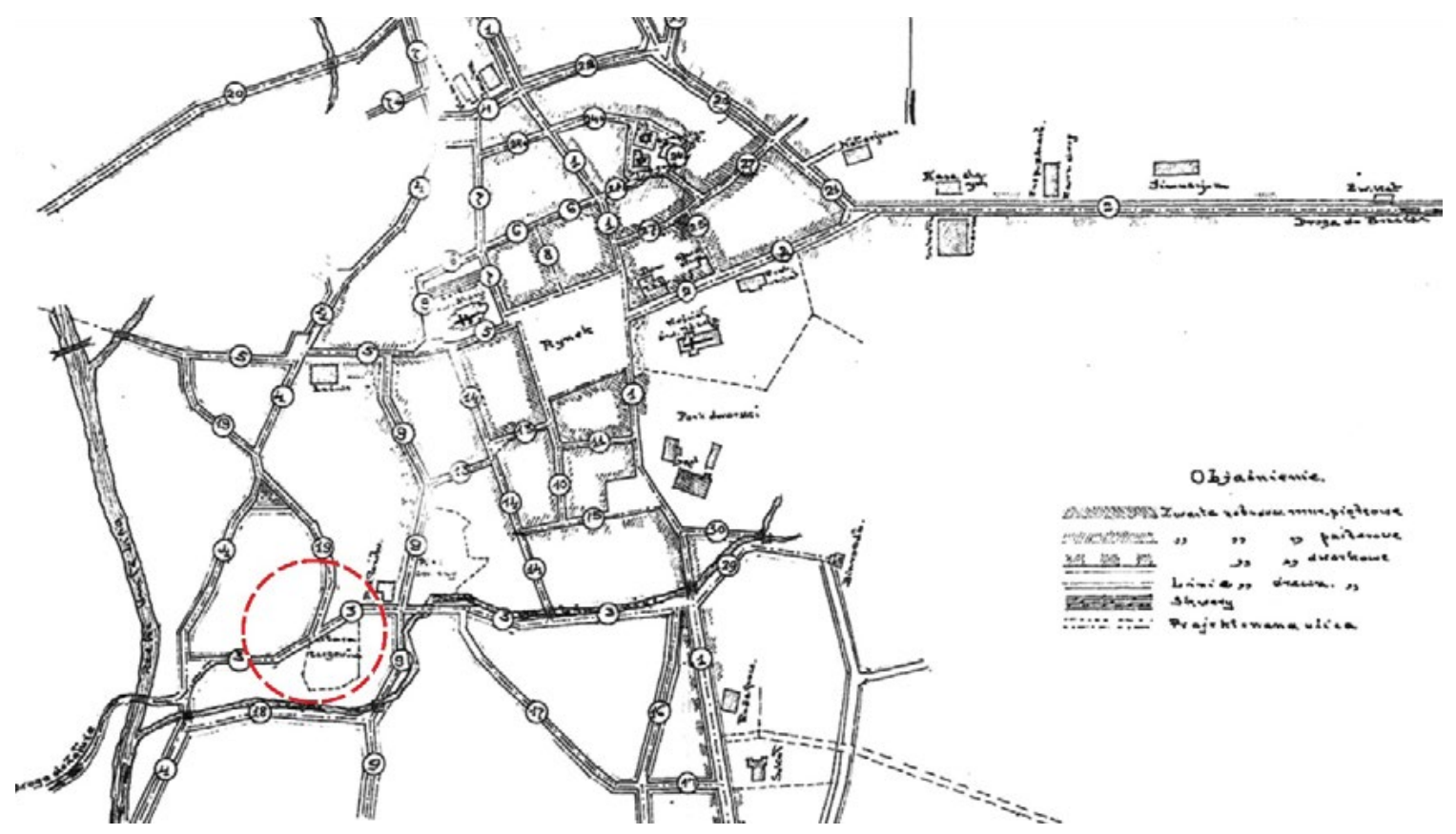

Fig. 18. Rohatyn town Plan of 1930 [http://www.rohatynrg.org/home/geography/city-maps]. The red circle marks the square in the New Town, which is labled as "Stara Targovica" (Old Market Square).

\section{Conclusions}

In the $16^{\text {th }}$ century, the middle town of Rohatyn was reconstructed after the catastrophe of 1509 , and a defensive girdle consisting of bastions was created around it, which also had an earth rampart, a moat, and a number of bastejas. This defensive line consisting of bastejas initially had a wooden fence on the ramparts. Subsequently, after the king's privilege of 1539, the wooden wall was replaced by a masonry wall. The key issue here is whether the system of bastejas was replaced by the system of bastions when the town switched to a masonry system of fortifications. The fact that there was such a change is confirmed by arguments presented in our study. The most important of them include documented remnants of such fortifications on cartographic materials dated 1861-1864. Records dated to the first half of the $20^{\text {th }}$ century about the remnants of the ramparts of the bastion plan and profile also support these conclusions. The photo of the building of a power station from the time of the First World War in which we see remnants of the masonry bastion curtain wall of the former castle is the most convincing argument. The remains of two bastions that were part of this curtain wall can be still identified on that location. You can also identify the bastion plan in the planning structure of the block between Pidvalna and Fortechna streets. 


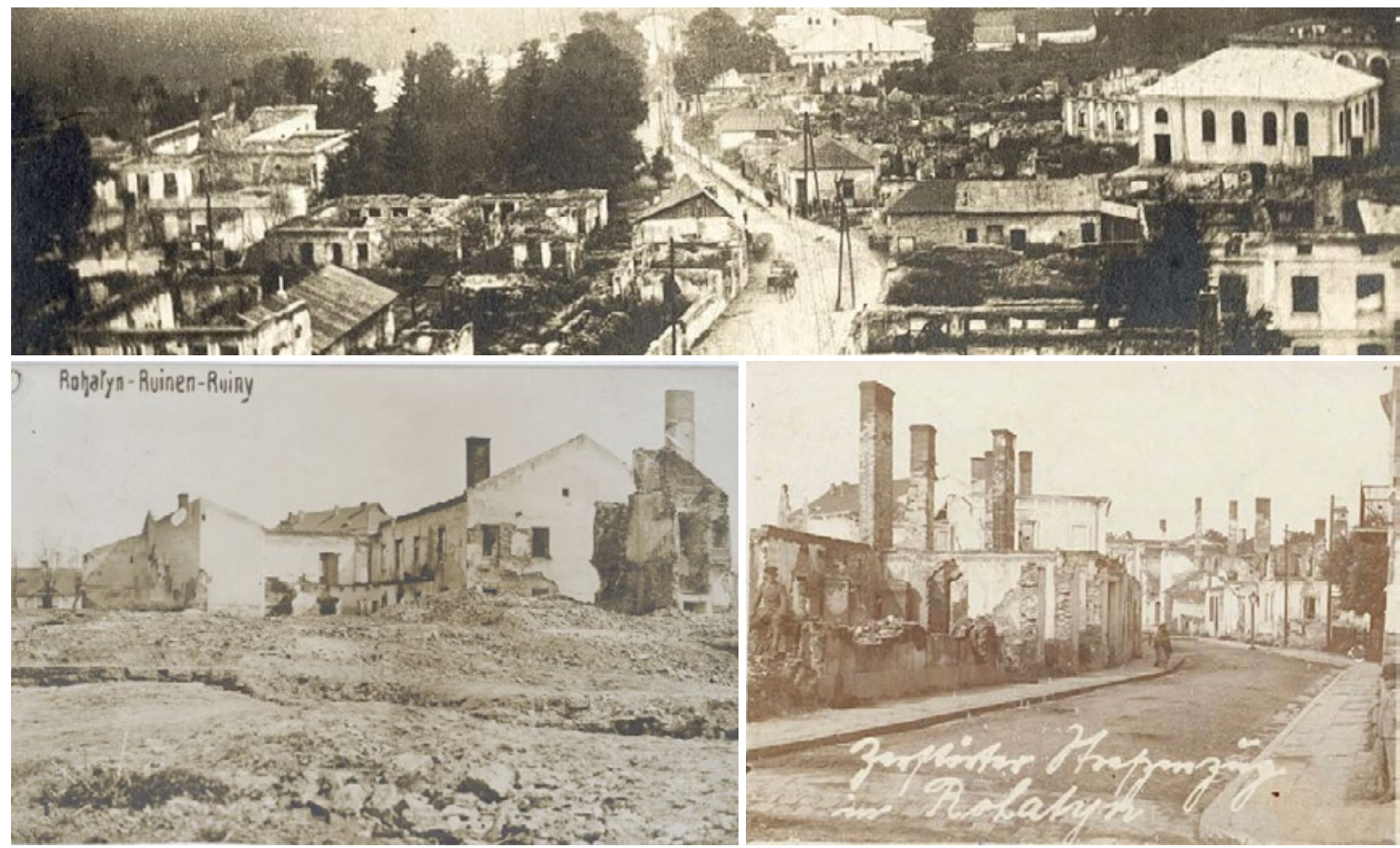

Fig. 19. Photos of the destruction of buildings in the central part of the town of Rohatyn at the time of World War I [polona.pl].

According to our hypothesis, the second fortification girdle consisting of bastions was created in the town later, at the end of the $16^{\text {th }}$ century. In particular, this technique was used for the fortification of the boundaries of the so-called New Town district and for the modernization of fortifications of the Old Town.

We suggest that the fortification history of the town is divided into four main stages:

- Stage $1^{\text {st }}$ - this is the period between 1415 (foundation of the town) and 1509 (complete destruction of the town as a result of the attack of the Wallachian-Turkish army under the leadership of Bogdan III the One-Eyed); at that time, the middle town and the castle, which were fortified with the help of a rampart and a moat, were created. Two gates and corner bastejas were erected on the rampart. A wooden fence was erected at the top of the rampart. The castle was fortified in a similar way as the middle town.

- The $2^{\text {nd }}$ stage - from 1509 until 1539. The town was being restored, and fortifications around the middle town and the castle were being built once again on the basis of new privileges of 1523, 1535, and 1539 . The middle town was somewhat expanded, new residential districts were created in place of old leveled ramparts. The fortifications initially had the form of a wooden fence on an earth rampart with triangular or polygonal bastejas (the privilege of 1535).

- The $3^{\text {rd }}$ period - from 1539 until the end of the $16^{\text {th }}$ century. Based on the privilege of 1539 , which created financial opportunities for the modernization of the defensive line, works related to the transformation of earth-wooden fortifications into masonry ones were undertaken. At the same time, the defensive girdle of the middle town received a new planning contour with bastions. The privilege of 1539 exempted the town from some taxes and obligated it to use the town's proceeds for the construction of masonry fortifications. There was another transformation which was important for the town: a so-called "New Town" with its girdle of earth bastion fortifications was laid to the west of the old middle town. At the end of this period, fortifications of the middle town and fortifications of the castle were also being modernized by switching from bastejas to bastions. During this period, the bastion line of fortifications of the middle town ("the old town") and the line of ramparts with bastions of the "New Town" existed concurrently and were maintained in proper condition.

- The $4^{\text {th }}$ period - in the $17^{\text {th }}$ century, territorial development of the town in the southern direction lead to the emergence of new residential districts and to the expansion of bastion fortifications to the east and 
south of the boundaries of the New Town. In the $18^{\text {th }}-19^{\text {th }}$ centuries, when fortifications were no longer relevant and had been dismantled, urban and suburban buildings were erected in their place.

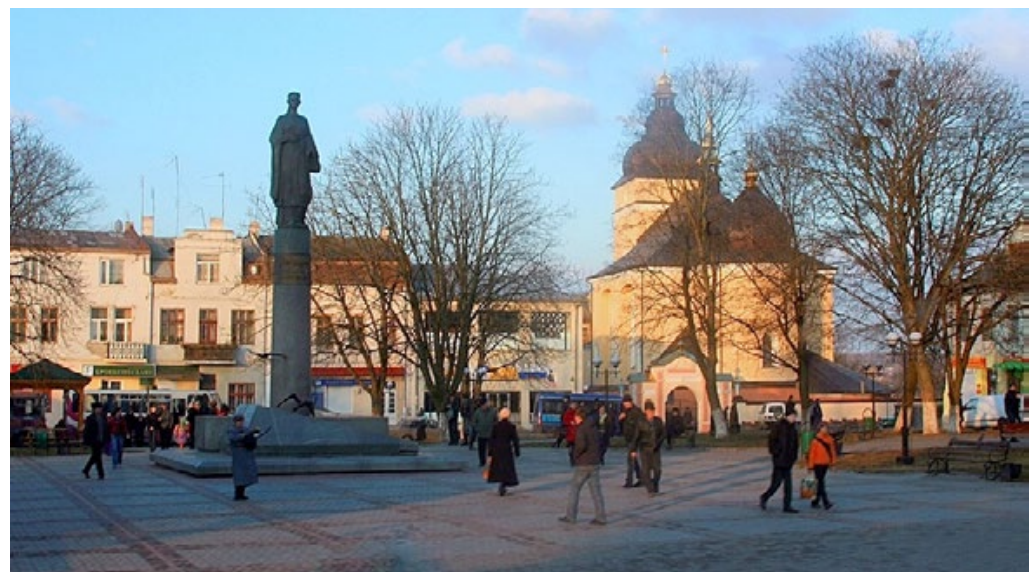

Fig. 20. The monument of Roksolana in the central square of the town of Rohatyn. It can also be considered a symbol of the destruction of the town in 1509 [photo: https://commons.wikimedia.org/w/index.php?curid $=4957881]$.

\section{References}

[1] M. Baliński, T. Lipiński (1844). Starożytna Polska pod względem historycznym, geograficznym, i statystycznym opisana. Warszawa, Naklad S. Orgelbranda, 1844, T. Il, s. 702-705; (http://books.google.com/books?id=Pvw KAAAAIAAJ\&amp;oe=UTF-8).

[2] Bevz M. (1996) Problema zberezhennya riznochasovykh mistobudivnykh istorychnykh kompleksiv u arkhitekturniy tkanyni mista. In: Urbanistychno-arkhitekturni problemy mist Halychyny, Zbirnyk naukovych prats', pid red. B. Cherkesa, M. Bevza. L'viv, DULP, 1996, s. 21-27.

[3] Bevz M. (1997) Arkhitekturno-prostorovyy uklad mista Zhovkvy v konteksti yevropeys'koyi urbanistyky. In: Zhovkva. Halyts'ka brama. L'viv: Tsentr Yevropy, 1997, №4 (28), s. 6-7.

[4] Bevz M. (1998) Zhovkva — renesansne „ideal'ne“ misto. Ukrayins'ka realizatsiya kontseptual'noyi ideyi z traktatu P'yetro Kataneo. In book: Istorychna, mystets'ka, arkhitekturna spadshchyna Zhovkvy. Problemy okhorony, restavratsiyi, vykorystannya. Zhovkva-L'viv, 1998,s. 36-43;

[5] Bevz M. (2000) Zberezhennya istorychnoho planuval'noho ukladu v proektakh reheneratsiyi zapovidnykh terytoriy istorychnykh mist. In book: Visnyk Natsional'noho universytetu "L'vivs'ka politekhnika". Arkhitektura. L'viv, 2000, №410, s. $62-69$.

[6] Bevz M. (2002) Studiyi arkhitekturno-mistobudivnoho rozvytku mista Belza XI-XX st. In: Visnyk instytutu "Ukrzakhidproektrestavratsiya". L'viv, 2002, Chyslo 12, s. 30-67.

[7] Franciszek Biesiadecki (1936). Herb krółewskiego miasta Rohatyna. Wydanie II. Lwów, odbitka z "Ziemi Czerweńskiej”, 1936, rocznik II, zeszyt 1, 7 s. (https://polona.pl/item/herb-krolewskiego-miasta-rohatyna,Njc4NTgxMDQ/11/\#item/);

[8] Czołowski A. (1930) Katastrofa Rohatyna 1509 r.: szkiz historyczny. Lwów, drukarnia Uniwersytecka, 1930.15 s.

[9] Istoryko-arkhitekturnyy opornyy plan mista Rohatyna (frahment). UDNPI «Dipromisto», 2007 r., avtory: Shumyn I., Shubelyak N., Senchak Z:;

[10] Książek M. (1992) Zarys budowy miast średniowiecznych w Polsce do konca XV wieku. Kraków, Politechnika Krakowska, 1992, 147 s.;

[11] Kuśnierz K. (1984) Sieniawa. Założenie rezydencjonalne Sieniawskich. Rozwój przestrzenny w XVII oraz XVIII wieku. Rzeszów, 1984, 258 s.;

[12] Matsyuk O. (1997) Zamky i fortetsi Zakhidnoyi Ukrayiny. L'viv, „Tsentr Yevropy”, 1997, s. 105-112;

[13] Mel'nyk V.I. (1991) Tserkva Svyatoho Dukha v Rohatyni. Al'bom. Kyyiv, "Mystetstvo", 1991, s. 5-15;

[14] Mohytych R. (1995) Rohatyn u systemi istorychnykh shlyakhiv. V: Rohatyns'ka zemlya: istoriya ta suchasnist'. Materialy pershoyi naukovoyi konferentsiyi, 24-25 bereznya 1995 r. - L'viv-Rohatyn: in-t Ukrayinoznavstva NANU. - 1995. - s. 86-88;

[15] Mohytych R. (1996) Rohatyn u systemi istorychnykh shlyakhiv. V zb.: Visnyk. Instytut «Ukrzakhidproektrestavratsiya». L'viv, 1996, chyslo 5, s. 24-26; 12. Okonchenko O. Evolyutsiya ob"yemno-prostorovoyi struktury bastionnykh zamkiv 
Zakhidnoyi Ukrayiny. V: Problemy doslidzhennya, zberezhennya i restavratsiyi ob"yektiv kul'turnoyi spadshchyny. Zbirnyk naukovykh prats' kafedry restavratsiyi i rekonstruktsiyi arkhitekturnykh kompleksiv. L'viv, NULP, 2014,s. 178-182;

[16] Naronowicz-Naroński Józef. Budownictwo wojenne (1659). Oswięcim, Napoleon-V, 2016. - $272 \mathrm{~s}$.

[17] Okonchenko O. (2011) Planuval'na struktura rannikh bastionnykh fortyfikatsiy zamkiv Zakhidnoyi Ukrayiny. In: Arkhitektura. Landshaft dakhiv istorychnoho tsentru mista: problemy zberezhennya i reheneratsiyi. Visnyk natsional'noho universytetu «L'vivs'ka politekhnika». L'viv, NULP, 2011, №716, s. 198-209;

[18] Pan'kiv B. (1995) Rohatyn drevniy, ukrayins'kyy. V: Rohatyns'ka zemlya: istoriya ta suchasnist'. Materialy pershoyi naukovoyi konferentsiyi, 24-25 bereznya 1995 r. - L'viv-Rohatyn: in-t Ukrayinoznavstva NANU, 1995, s. 24-26;

[19] Słownik (1888) geograficzny Królestwa Polskiego i innych krajów słowiańskich. — Warszawa : Filip Sulimierski i Władysław Walewski, 1888. - T. IX : Poźajście - Ruksze;

[20] Tsar'ova N. (1995) Pryvileyi Volchka Presluzhycha na nadannya Mahdeburz'koho prava novozasnovanomu mistu Rohatynu. V: Rohatyns'ka zemlya: istoriya ta suchasnist'. Materialy pershoyi naukovoyi konferentsiyi, 24-25 bereznya 1995 r. - L'viv-Rohatyn: in-t Ukrayinoznavstva NANU, 1995, s. 91-99;

[21] Yasins'kyy M. (2013) Oboronni elementy v strukturi mista Rohatyna ta yikh vplyv na rozvytok zhytlovoyi zabudovy. V: Problemy doslidzhennya, zberezhennya i restavratsiyi istorychnykh fortyfikatsiy. L'viv, NULP, 2013, №4, s. 154-157;

[22] Wróbłewska G. Rozplanowanie miast nowożytnych w Wielkopolsce od XVI do końca XVIII wieku. Warszawa-Poznań, PWN, 1977, 220 s.;

[23] Mieczysław Dunin Wąsowicz (1869). Rohatyn. Miasto krółewskie. Krótki opis tego miejsca. Kraków, w drukarni Uniwersytetu Jagellońskiego, 1869, 14 s. (https://polona.pl/item/rohatyn-miasto-krolewskie-krotki-opis-tegomiejsca,NzcxMTAy/1/ \#item/);

[24] Zinchenko S. (1995) In: Rohatyns'ka zemlya: istoriya ta suchasnist'. Materialy pershoyi naukovoyi konferentsiyi, 24-25 bereznya 1995 r., L'viv-Rohatyn: in-t Ukrayinoznavstva NANU, 1995, s. 174-175;

[25] Jan Sas Zubrzycki (1914). Rohatyn miasto krółewskie. W Krakowie, nakładem Akademii Umiejętności, odbito w drukarni uniwersytetu Jagellońskiego, 1914, 14 s. (https://polona.pl/item/rohatyn-miasto-krolewskie,NTIzNTAw);

[26] http://www.rohatynrg.org/home/geography/1944-rohatyn-aerial;

[27] https://get.google.com /albumarchive/104519598602010189193/album/ (1668-1728);

[28] http://www.rohatynrg.org/home/geography/city-mapsRohatynResearchGroup;

[29] https://polona.pl/item/fragment-obrazu-z-cerkwi-sw-mikolaja-przedstawiajacego-oblezenie-rohatyna-przez-tatarow,NjczODcyNTc/0/\#item/fragmentobrazuzcerkwisw.Mikolaja;

[30] https://polona.pl/item/powiat-rohatynski,MTU4MzMwNA/powiatrohatynski;

[31] http://rohatynjewishheritage.org/en /maps/1846- cadastral/;

[32] http://www.rsrg.org/rohatyn /map/overlay-1846-cadastral/Rukopysnyy kadastrovyy plan, nakladenyy na suchasnu kartu;

[33] http://rohatynjewishheritage.orgro6/en/maps/1944-aerial-photo/;

[34] https://www.google. com.ua /search?q=Rohatyn\&tbm=isch\&tbs=rimg;

[35] http://mapire.eu/en/map/secondsurvey/1861-1864.

[36] https://uk.wikipedia.org/wiki/ Rohatyn.

[37] https://de.wikipedia.org/wiki/Bastei(Festung).

\section{Hipotetyczna rekonstrukcja faz rozwojowych systemu obronnego śródmieścia miasta Rohatyna w XV-XVII w.}

Anotacja: Na przykładzie Rohatyna, miasta w Ukrainie Zachodniej, prezentujemy etapy rozwoju architektury obronnej śródmiescia. Argumentacja bazuje się na analizie struktury planistycznej miasta, na analizie materiału kartograficznego historycznego i wspolczesnego, badaniach terenowych szczatkỏw fortyfikacji, analizie dokumentów historycznych, analizie fortyfikacji budowanej w miastach-sąsiadach. Historia budowy linii obronnych dookola śródmiescia Rohatyna rekonstruje się na cztery główne faze, przentujące ciekawe drogi modernizacji umocnien od typu parkanu drewnianego do murowanych bastionów.

Slowa kluczowe: miasto Rohatyn, śródmiescie, fortyfikacja, basteja, bastion, XV-XVII wiek. 